\title{
Factors of career mobility in Egypt by gender
}

May Gadallah

Follow this and additional works at: https://knowledgecommons.popcouncil.org/departments_sbsr-pgy

Part of the Demography, Population, and Ecology Commons, Family, Life Course, and Society Commons, Gender and Sexuality Commons, International Public Health Commons, Labor Economics Commons, and the Work, Economy and Organizations Commons How does access to this work benefit you? Let us know!

\section{Recommended Citation}

Gadallah, May. 2011. "Factors of career mobility in Egypt by gender," Gender and Work in the MENA Region Working Paper no. 16. Cairo: Population Council. 


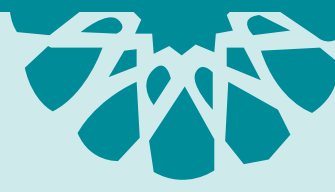

Factors of Career Mobility in Egypt by Gender

May Gadallah 
May Gadallah is an Assistant Professor, Department of Statistics, Faculty of Economics and Political Science, Cairo University, Cairo, Egypt. Email: mayabaza@hotmail.com

The research presented in this publication is the result of a project funded by Canada's International Development Research Centre (www.idrc.ca).

\section{IDRC * CRDI}

Canadä

\section{(f) Population Council}

Research that makes a difference

The Population Council confronts critical health and development issues-from stopping the spread of HIV to improving reproductive health and ensuring that young people lead full and productive lives. Through biomedical, social science and public health research in 50 countries, the Council works with our partners to deliver solutions that lead to more effective policies, programs, and technologies to improve lives worldwide. Established in 1952 and headquartered in New York, the Council is a nongovernmental, nonprofit organization with an international board of trustees.

Population Council

Egypt Office

59 Misr Helwan Agricultural Road, Maadi, Cairo, Egypt

Tel.: (+202) 2525-5965, (+202) 2525-5967, (+202) 2525-5968

Facsimile: (+202) 2525-5962

Website: http://www.popcouncil.org

Email: pcouncil@popcouncil.org

(c) 2011 The Population Council, Inc.

Any part of this publication may be reproduced without permission for limited distribution, provided it is distributed without charge and the Population Council is acknowledged as its source. The Population Council would appreciate receiving a copy of any materials in which the text is used.

ISSN: 11870/2011 
NUMBER 16

JUNE 2011

GENDER AND WORK IN THE MENA REGION

WORKING PAPER SERIES

Poverty, Job Quality and Labor Market Dynamics

\section{Factors of Career Mobility in Egypt by Gender}

May Gadallah 



\section{Table of contents}

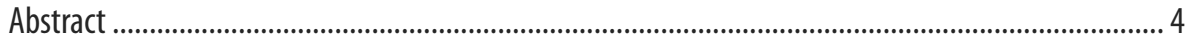

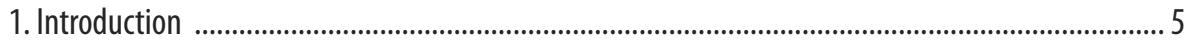

1.1 Quick Overview of the Egyptian Labor Market .......................................................................

1.2 Conceptual Framework and Objectives of the Study .............................................................. 6

1.3 Measuring Career Development by Gender ........................................................................

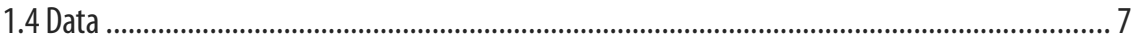

2. Descriptive Analysis ....................................................................................................... 9

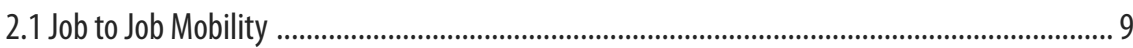

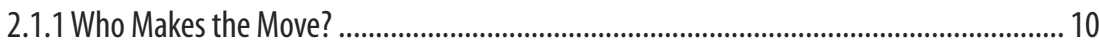

2.1.2 Movement Direction ..................................................................................................... 11

2.1.3 The Impact of the First Job Security Index on Current Job Status.....................................13

2.2 Career Mobility over a Period of Eight Years ........................................................................ 14

2.2.1 Status Mobility between 1998 and 2006 ................................................................ 14

2.2.2 Job Security Mobility between 1998 and 2006 ........................................................ 17

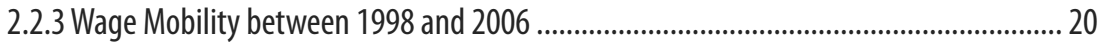

2.2.4 The Wage/Security Tradeoff ........................................................................................ 21

3. Determining the Main Factors of Career Mobility by Gender ......................................................... 22

3.1 Multivariate Analysis ............................................................................................... 22

3.2 Methodology ....................................................................................................... 23

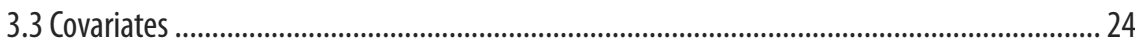

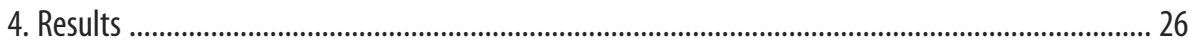

4.1 Whether or not to Continue as a Waged Worker .................................................................. 26

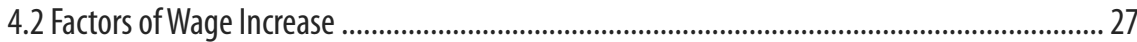

4.3 Factors of Job Security Increase ................................................................................. 28

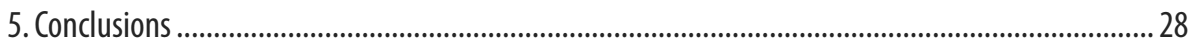

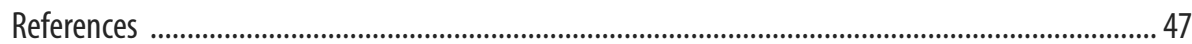

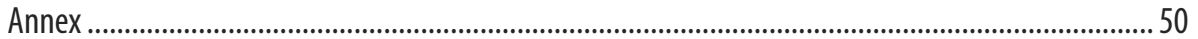


Women's participation in the labor market has drawn the attention of many researchers in Egypt. Gender differences extend from the labor structure to wages and salaries earned.

Career mobility and job to job transition in the Egyptian labor market has received less attention. One of the major motivations of this study is the belief in the "systematic" mobility of women in the labor market. The career path of women is pre-determined in Egyptian culture. For women who complete intermediate education or above, they enter the labor market through a government job. This concept has changed among recent cohorts as more women complete intermediate education, few of them decide to work, and even fewer are able to get a government job, and even fewer keep their jobs. Through women's career life it is important to study whether they really move upward and if there are certain factors which determine their mobility within the labor market, or even quitting the labor market, and how these determinants differ by gender.

The paper focuses on a critical determinant, not only of participating in the labor market, but also of continuing in it: the opportunity cost of women's participation in the labor market. It is believed that the opportunity cost of not working increases if the compensation consists of both wages and secure job conditions. The opportunity cost of not working decreases with the lack of secure conditions. For women with low compensation in terms of wages and secure conditions, their opportunity cost of not working decreases with marriage, which increases the probability of quitting the labor market.

The target group in this paper is males and females in Egypt aged I8-64 years, who have an intermediate or above educational degree, and are working as waged workers. The data used is from the 1998 ELMS (Egypt Labor Market Survey) and 2006 ELMPS (Egypt Labor Market Panel Survey), using the advantage of having a subset panel sample in both years.

Career mobility is measured, and job to job turnover by gender is observed in the paper. Career development over eight years and the impact of different factors on this development are analyzed. Probit models with sample selection and Heckman selection models are used in the analyses. 
The importance of the results increases with the privatization trend in the Egyptian economy in the previous decades. Male and female in the private sector workers are in a more critical condition, and as the private sector expands and absorbs more of the new labor market entrants, more attention should be paid to them. Those new entrants are challenged by the tradeoff between wages and job security. Those who fail in getting engaged in the public sector of all males and young females have higher probability of ending up with low secured jobs.

Low wages and low job security are the main reasons for a woman to quit working, once she gets married.

\section{Introduction}

\subsection{Quick Overview of the Egyptian Labor Market}

Labor force participation rates increased between 1998 and 2006 by about $5 \%$ among both males and females, reaching $78.5 \%$, and $26.9 \%$, respectively. The share of waged work among females is higher than males, at $55 \%$ compared to $33 \%$ in 2006 . Most women waged workers are engaged in the government or public sector, at $38 \%$ of all employed women compared to $28 \%$ of employed men (Assaad and Hamidi 2009). If we restrict these statistics to the intermediate education level and above, the participation rate increases to about $32 \%$ among females; $89 \%$ of them are engaged in waged work and the government (or public) share is equal to about $78 \%$ of waged women.

Although the government/public sector dominates the waged work of educated females, (See Figure A-I and Table A-I), there is an increasing trend among the younger generation towards joining the private sector despite their lower participation rate.

For males, only $76 \%$ of those with an intermediate or above education in the labor force are waged workers; around $50 \%$ of them are government or public sector workers.

Women's participation in the labor market has drawn the attention of many researchers in Egypt, in particular with regard to gender differences. Some studies have focused on gender wage differentials. Assaad (I997) studied wage differentials by gender and sector; one of his findings was that females with an intermediate education appeared to face considerable discrimination in the private sector. El Haddad (2009) used both the 1998 and the 2006 ELMPS data sets to study wage differentials by gender; she concluded there is an existing wage gap in the private sector in favor of men. 
Career mobility and job to job transition in the Egyptian labor market have received less attention. Ahlburgand Amer (2003) analyzed the employment status mobility of Egyptian youth aged 15-29 between I988 and 1998 using the ELMS data of 1998. Amer and Simonnet (2008) provided an in-depth analysis of the determinants of employment duration and the number of changes in status between 1998 and 2006 using the data of ELMPS 2006. The paper indicated the importance of first employment status for employment duration.

This paper focuses on transitions, and differences in career path during these transitions, by gender, analyzing career development by moving from job to job and the achievements made between two fixed times in individuals' working life.

\subsection{Conceptual Framework and Objectives of the Study}

One of the major motivations of this study is the belief in the "systematic" mobility of women in the labor market. The career path of women is predetermined in Egyptian culture. Women who complete intermediate or above education enter the labor market through a government job. This concept has changed among recent cohorts; as seen in Figure A-r, more women complete intermediate education, few of them decide to work, even fewer are able to get a government job, and even fewer keep their jobs. Through women's career life, it is important to study whether they really move upward and if there are certain factors that determine their mobility within the labor market - or even leaving the labor market - and how these determinants vary by gender.

This paper also focuses on a critical determinant, not only of participating in the labor market, but also of continuing in it: the opportunity cost of women's participation in the labor market. It is believed that the opportunity cost of not working increases if the compensation consists of both wages and secure job conditions. The opportunity cost of not working decreases with the lack of secure conditions. For women with low compensations in terms of wages and secure conditions, the opportunity cost of not working decreases with marriage, increasing the probability that they will quit the labor market.

\section{The main objectives of the study are as follows:}

- Measuring the career mobility offemales and males, and the effect of job mobility on their career mobility by studying job to job turnover.

- Observing career development over a period of eight years, and analyzing the impact of different factors on career development by gender. 
The analysis in this paper is descriptive; it covers the first objective and the description of the career mobility over eight years, and multivariate, which analyzes the determinants of this career development.

The target group in this paper is the group of males and females in Egypt aged 18-64, with an intermediate or above education degree and who are working as waged workers.

\subsection{Measuring Career Development by Gender}

One of the methods used in judging career development is occupational mobility, measured by the occupation rank, which is also used as a predictor of wage change. A rank based on a two-digit code for the occupation was used in analyzing occupational mobility by Waddoup and Assane (1993), Buchel and Mertens (2000), Maltseva (2005), and Dex et al. (2007).

Wage change over time is also considered a measure of career mobility, which is based on the proposition that upward career mobility is associated with wage increase (Buchel and Mertens, 2000, Welch, 2000).

A third method of measuring career development is considering job quality and changes that occur from the start point 1998 to the end point 2006. A job quality index was introduced by Assaad et al (2009); the index was based on working conditions, job security and income. Upward mobility will be obtained if the index increases. The index was heavily weighted by job security conditions, which is also considered a measure of career mobility (to move to a more secure job). ${ }^{1}$

In this paper the scarcity of observations for women's two-digit occupation codes was an obstacle to studying occupational mobility, therefore it is not considered. The two career measurements considered in this paper are hourly wage mobility between 1998 and 2006, and job quality, measured only by job "security" or "formality", separating the two concepts in order to study the differences in career mobility by these measurements.

\subsection{Data}

This paper uses the data of the I998 ELMS (Egyptian Labor Market Survey) and 2006 ELMPS (Egypt Labor Market Panel Survey), using the advantage of having a subset panel sample in both years.

The data set provides information for job history, including first, second, third, and current jobs. While the current job has detailed information, including wages, the information provided for the job history includes only the job characteristics of employment status, stability, occupation, economic activity, availability of contract, and social security. The panel

1 It might also be considered as moving to a formal job. 
sample provides detailed information about the jobs occupied in 1998 and 2006 , including wages.

The number of observations in each data set is as follows:

Table 1: Sample Size in 1998 ELMS and 2006 ELMPS

\begin{tabular}{|l|c|c|}
\hline & Males & Females \\
\hline Individuals 26-64 & 2,111 & 1,540 \\
\hline Employed 26-64 in 1998 or 2006 & 2,053 & 1,028 \\
\hline Waged 26-64 in 1998 or 2006 & 1,681 & 761 \\
\hline Waged 26-64 in 1998 and 2006 & 1,100 & 515 \\
\hline
\end{tabular}

* Based on 2006 age criteria

Source: Based on author's calculations from ELMS and ELMPS

Wage:

The hourly wage variable is constructed based only on the primary job in the previous 3 months for both data sets of 1998 and 2006 . The real hourly wage for 1998 is computed and compared with that of 2006 by gender. The comparisons include the change between 1998 and 2006 in general, and the change for those who were waged workers in 1998 and continued as waged workers in 2006.

\section{Fob 2uality (Secured Fob Index):}

Stability and security of work are important dimensions of a "decent" job (Anker 2002). The variables used in constructing the job security index are based on social protection and stability. The social protection is measured by the presence of a contract, social security, paid leave of absence, medical insurance and membership in unions. Job stability is measured, in addition to the job stability itself, by the job's requirements for skills, and receiving promotions in the job or not since promotions and skill requirements may be reasons to have a stable job. The nature of the workplace ${ }^{2}$ was also included in constructing the job security index,

The job security index is computed twice?:

2 By workplace it is meant in or out an establishment.

3 As most of the variables are binary or at least ordinal, the polychoric correlation was used to construct an index for job quality (security).

Both factor analysis and polychoric correlation are applied and compared based on the score distribution and classification. As there was only a slight difference between the two techniques, factor analysis is used. 
First, based on the pooled sample of 1998 and $2006^{4}$ waged workers aged I8-64, in order to impute the job security factor scores in both years based on the same variable weights. These scores are used in examining job security mobility between 1998 and 2006 .

Second, based on the 2006 sample of waged workers aged i 8-64. These index scores are used to impute job security for the first, second and third jobs based on the characteristics of these jobs (Assaad et al. 2009, Assaad, et al. 20IO). These indices are used to study the impact of job mobility on job security.

\section{Descriptive Analysis}

\subsection{Job to Job Mobility}

Assaad et al (2010) observed that only $28 \%$ of the male youth aged $15^{-}$ 34 start with a "good" job that is a secure, stable formal job. They have to wait a longer time after finishing school to start with this high quality job. Those who start with regular and irregular informal work have higher rates of transitioning to a second job (Assaad et al. 20IO).

Comparing job turnover between females and males, Table 2 shows that females have lower job turnover than males by about $50 \%$, reflecting the fact that they start with higher quality jobs than males, and therefore are less likely to transition to another job. The turnover is higher among older age groups, both male and female.

Table 2: Number of Job Turnovers by Gender and Age

\begin{tabular}{|l|c|c|c|c|}
\hline \multirow{2}{*}{ Number of Jobs } & \multicolumn{2}{|c|}{ Male } & \multicolumn{2}{c|}{ Female } \\
\hline & $18-40$ & $41-64$ & $18-40$ & $41-64$ \\
\hline One Job & $45.6 \%$ & $26.5 \%$ & $69.9 \%$ & $49.9 \%$ \\
\hline 2 Jobs & $41.0 \%$ & $44.9 \%$ & $26.1 \%$ & $38.0 \%$ \\
\hline 3 or More Jobs & $13.5 \%$ & $28.6 \%$ & $4.0 \%$ & $12.1 \%$ \\
\hline Total & 3,417 & 1,349 & 1,170 & 673 \\
\hline
\end{tabular}

Source: Based on author's calculations from ELMPS

4 Computations were based on the whole samples, and comparisons were done for the panel sample. 


\subsubsection{Who Makes the Move?}

Tables 3, 4, and 5 calculate the average job security of the first, second, and third jobs, respectively, clarifying the impact of job security on the transition to another job. For the Younger age groups, both females and males who transition to two or more jobs had low quality jobs to start with. They hoped to improve their job security by job transition. Those who start with very low job security do not stop at the second job; they keep transiting to a third job in order to increase their job security. Job security increases smoothly for older females, part of it is properly a systematic career promotions. As for older males, those who keep transitioning have significantly lower job security than those who maintain one job.

Table 3: Mean Job Security Index for the First Job by Job Turnover, Gender, and Age

\begin{tabular}{|l|c|c|c|c|}
\hline Number of Jobs & \multicolumn{3}{|c|}{ Female } & \multicolumn{2}{c|}{ Male } \\
\hline \multirow{4}{*}{ One } & $18-40$ & $41-64$ & $18-40$ & $41-64$ \\
\hline \multirow{4}{*}{ Two } & 0.15 & 0.87 & -0.07 & 0.86 \\
& $(0.89)$ & $(0.29)$ & $(0.95)$ & $(0.31)$ \\
& 750 & 290 & 1051 & 281 \\
\hline \multirow{4}{*}{ Three or more } & -0.04 & 0.80 & -0.60 & 0.54 \\
& $(0.83)$ & $(0.42)$ & $(0.88)$ & $(0.74)$ \\
& 284 & 238 & 849 & 443 \\
\hline
\end{tabular}

Source: Based on author's calculations from ELMPS

Number between brackets is the standard deviation; third number is number of observations

Table 4: Mean Job Security Index for the Second Job by Job Turnover, Gender, and Age

\begin{tabular}{|l|c|c|c|c|}
\hline Number of Jobs & \multicolumn{3}{|c|}{ Female } & \multicolumn{2}{c|}{ Male } \\
\hline & $18-40$ & $41-64$ & $18-40$ & $41-64$ \\
\hline \multirow{3}{*}{ Second } & 0.23 & 0.96 & -0.13 & 0.84 \\
& $(0.81)$ & $(0.19)$ & $(0.94)$ & $(0.41)$ \\
& 280 & 233 & 887 & 466 \\
\hline \multirow{3}{*}{ Third } & -0.21 & 0.85 & -0.56 & 0.33 \\
& $(0.88)$ & $(0.36)$ & $(0.85)$ & $(0.88)$ \\
& 49 & 74 & 304 & 240 \\
\hline
\end{tabular}

Source: Based on author's calculations from ELMPS

Number between brackets is the standard deviation; third number is number of observations 
Table 5: Mean Job Security Index for the Third Job by Gender and Age

\begin{tabular}{|l|c|c|c|c|}
\hline $\begin{array}{l}\text { The Job Security } \\
\text { Index of Third Job }\end{array}$ & \multicolumn{2}{|c|}{ Female } & \multicolumn{2}{c|}{ Male } \\
\hline & $18-40$ & $41-64$ & $18-40$ & $41-64$ \\
\hline \multirow{3}{*}{ Third } & 0.33 & 0.95 & 0.07 & 0.74 \\
& $(0.85)$ & $(0.35)$ & $(0.90)$ & $(0.58)$ \\
& 47 & 73 & 331 & 251 \\
\hline
\end{tabular}

Source: Based on author's calculations from ELMPS

Number between brackets is the standard deviation; third number is number of observations

\subsubsection{Movement Direction}

As previously explained, those with lower job security try to improve their conditions by transitioning to a second job. Generally almost half of those who moved were able to improve their work conditions, with slight differences by gender and age group. Those who moved upward were young in age with the least job security in their first job. A higher percentage of young females $(27 \%)$ than males (21\%) moved downward, with a greater magnitude of job security index (0.4I down for females vs. 0.32 for males). Downward moves decreased among older females, with almost no impact of the job security index on the direction of transition among older groups.

Table 6: Transition Direction and Magnitude of Job Security Index from First to Second Job by Gender Age Group 18-40

\begin{tabular}{|l|c|c|c|c|c|c|}
\hline & \multicolumn{3}{|c|}{ Male } & \multicolumn{3}{c|}{ Female } \\
\hline $\begin{array}{l}\text { Mobility } \\
\text { Direction }\end{array}$ & $\%$ & $\begin{array}{c}\text { Quality of } \\
\text { First Job } \\
\text { (Median) }\end{array}$ & $\begin{array}{c}\text { Average } \\
\text { Change }\end{array}$ & $\%$ & $\begin{array}{c}\text { Quality of } \\
\text { First Job } \\
\text { (Median) }\end{array}$ & $\begin{array}{c}\text { Average } \\
\text { Change }\end{array}$ \\
\hline Downward & $20.9 \%$ & -.61 & -0.32 & $27.1 \%$ & 0.26 & -0.41 \\
\hline & $(188)$ & & & $(81)$ & & \\
\hline No Change & $22.6 \%$ & -0.82 & 0.00 & $22.4 \%$ & 0.90 & 0.00 \\
\hline & $(206)$ & & & $(73)$ & & \\
\hline Upward & $56.6 \%$ & -1.11 & 0.78 & $50.5 \%$ & -0.68 & 0.68 \\
\hline & $(487)$ & & & $(152)$ & & \\
\hline
\end{tabular}

Source: Based on author's calculations from ELMPS

Numbers between brackets are observation numbers 
Table 7: Transition Direction and Magnitude of Job Security Index from First to Second Job by Gender, Age Group 41-64

\begin{tabular}{|l|c|c|c|c|c|c|}
\hline & \multicolumn{3}{|c|}{ Male } & \multicolumn{3}{c|}{ Female } \\
\hline $\begin{array}{l}\text { Mobility } \\
\text { Direction }\end{array}$ & $\%$ & $\begin{array}{c}\text { Quality of } \\
\text { First Job } \\
\text { (Median) }\end{array}$ & $\begin{array}{c}\text { Average } \\
\text { Change }\end{array}$ & $\%$ & $\begin{array}{c}\text { Quality of } \\
\text { First Job } \\
\text { (Median) }\end{array}$ & $\begin{array}{c}\text { Average } \\
\text { Change }\end{array}$ \\
\hline Downward & $19.9 \%$ & 0.90 & -0.28 & $13.1 \%$ & 0.92 & -0.11 \\
\hline & $(112)$ & & & $(44)$ & & \\
\hline No Change & $25.2 \%$ & 0.90 & 0.00 & $34.7 \%$ & 0.93 & 0.00 \\
\hline & $(156)$ & & & $(100)$ & & \\
\hline Upward & $55 \%$ & 0.89 & 0.48 & $52.3 \%$ & 0.92 & 0.27 \\
\hline & $(349)$ & & & $(177)$ & & \\
\hline
\end{tabular}

Source: Based on author's calculations from ELMPS

Numbers between brackets are observation numbers

\section{Sector transition}

Since the public sector represents the more formal and secure sector in terms of the availability of a contract, social security, paid leave of absence, and medical insurance, waged workers in the public sector have lower turnover than those in the private sector. The numbers in the following tables reflect the same conclusions that females are more likely to be engaged in public sector work, with a higher percentage among older age groups. The sector distribution among waged workers remains almost the same in the first and second jobs for all groups, indicating that the increasing share of private sector employment among young age groups remains even after changing jobs.

Table 8: Sector Transition from First to Second Job by Gender, Age Group 18-40

\begin{tabular}{|c|c|c|c|c|c|c|c|c|}
\hline & \multicolumn{3}{|c|}{ Male 18-40 } & \multicolumn{3}{c|}{ Female 18-40 } \\
\hline Second Job & G/Pub & Priv. & $\begin{array}{c}\text { Didn't } \\
\text { transit }\end{array}$ & Total & G/Pub & Priv. & $\begin{array}{c}\text { Didn't } \\
\text { transit }\end{array}$ & Total \\
\hline $\begin{array}{c}\text { Government/ } \\
\text { Public }\end{array}$ & $29.2 \%$ & $7.1 \%$ & $63.7 \%$ & $\begin{array}{c}100 \% \\
(25 \%)\end{array}$ & $26.4 \%$ & $1.7 \%$ & $71.9 \%$ & $\begin{array}{c}100 \% \\
(57.4 \%)\end{array}$ \\
\hline Private & $8.2 \%$ & $53.1 \%$ & $38.7 \%$ & $\begin{array}{c}100 \% \\
(75 \%)\end{array}$ & $6.6 \%$ & $27.0 \%$ & $66.5 \%$ & $\begin{array}{c}100 \% \\
(42.6 \%)\end{array}$ \\
\hline $\begin{array}{c}\text { Sector of the 2 } \\
\text { Job (waged) }\end{array}$ & $27.6 \%$ & $72.4 \%$ & & & $59 \%$ & $41 \%$ & & \\
\hline
\end{tabular}

Source: Based on author's calculations from ELMPS

Numbers between brackets are sector distributions of first job 
Table 9: Sector Transition from First to Second Job by Gender, Age Group 41-64

\begin{tabular}{|c|c|c|c|c|c|c|c|c|}
\hline & \multicolumn{3}{|c|}{ Male 41-64 } & \multicolumn{3}{c|}{ Female 41-64 } \\
\hline $\begin{array}{c}\text { Sirst Job } \\
\text { Government/ } \\
\text { Public }\end{array}$ & G/Pub & Priv. & $\begin{array}{c}\text { Didn't } \\
\text { transit }\end{array}$ & Total & G/Pub & Priv. & $\begin{array}{c}\text { Didn't } \\
\text { transit }\end{array}$ & Total \\
\hline Private & $30.8 \%$ & $10.2 \%$ & $36 \%$ & $\begin{array}{c}100 \% \\
(69.8 \%)\end{array}$ & $47.2 \%$ & $1.7 \%$ & $51.1 \%$ & $\begin{array}{c}100 \% \\
(92.2 \%)\end{array}$ \\
\hline $\begin{array}{c}\text { Sector of the 2 } \\
\text { Job (waged) }\end{array}$ & $70.9 \%$ & $28.1 \%$ & $8.7 \%$ & $\begin{array}{c}100 \% \\
(30.2 \%)\end{array}$ & $22 \%$ & $34.4 \%$ & $43.6 \%$ & $\begin{array}{c}100 \% \\
(7.8 \%)\end{array}$ \\
\hline
\end{tabular}

Source: Based on author's calculations from ELMPS

Numbers between brackets are sector distributions of first job

\subsubsection{The Impact of the First Job Security Index on Current Job Status}

Assaad et al. (2010) showed that the duration of getting a job among younger males decreases as they start with a less secure job instead of waiting for a "good" job. Table Io confirms these findings as we notice that the quality of the first job among the older group is higher than the younger group for both females and males. About one-fourth of young males who started with a waged job ended up as non - waged, due to the low job security they started with. Young females who start with a low security job are more likely to end up as non-waged workers, unemployed, or even quit the labor market to become housewives.

Table 10: Mean Job Security Index of the First Job by Current Employment Status, by Gender and Age

\begin{tabular}{|l|c|c|c|c|c|c|c|c|}
\hline \multirow{4}{*}{ Status in 2006 } & \multicolumn{4}{|c|}{ Age 18-40 } & \multicolumn{4}{c|}{ Age 41-64 } \\
\cline { 2 - 10 } & \multicolumn{2}{|c|}{ Male } & \multicolumn{2}{c|}{ Female } & \multicolumn{2}{c|}{ Male } & \multicolumn{2}{c|}{ Female } \\
\cline { 2 - 10 } & $\begin{array}{c}\text { Quality } \\
\text { of First } \\
\text { Job }\end{array}$ & $\begin{array}{c}\text { \% of } \\
\text { Current } \\
\text { Status }\end{array}$ & $\begin{array}{c}\text { Quality } \\
\text { of First } \\
\text { Job }\end{array}$ & $\begin{array}{c}\text { \% of } \\
\text { Current } \\
\text { Status }\end{array}$ & $\begin{array}{c}\text { Quality } \\
\text { of First } \\
\text { Job }\end{array}$ & $\begin{array}{c}\text { \% of } \\
\text { Current } \\
\text { Status }\end{array}$ & $\begin{array}{c}\text { Quality } \\
\text { of First } \\
\text { Job }\end{array}$ & $\begin{array}{c}\% \text { of } \\
\text { Current } \\
\text { Status }\end{array}$ \\
\hline Waged & -0.31 & 71.68 & 0.22 & 66.32 & 0.57 & 76.82 & 0.85 & 79.19 \\
\hline Non Waged & -0.92 & 26.18 & -0.60 & 11.86 & 0.01 & 14.84 & 0.27 & 3.58 \\
\hline Unemployed & -0.93 & 2.04 & -0.80 & 4.69 & -0.31 & 0.53 &. & - \\
\hline Housewife & - & - & -0.55 & 14.28 & - & - & 0.57 & 6.6 \\
\hline $\begin{array}{l}\text { Leave for Child } \\
\text { Care }\end{array}$ & - & - & 0.87 & 2.85 & - & - & 0.98 & 0.61 \\
\hline Retired & - & $<0.5$ & - & - & 0.87 & 7.77 & 0.83 & 9.87 \\
\hline
\end{tabular}

Source: Based on author's calculations from ELMPS 


\subsection{Career Mobility over a Period of Eight Years}

One of the main advantages of the dataset is the availability of a panel subset that allows us to follow up on individual career mobility over a period of eight years. This follow up permits an in-depth analysis of the intra-generational mobility of individuals in their career life in Egypt. What do educated waged workers accomplish in their career life in terms of job quality and money? How do these achievements differ according to gender?

This section observes career mobility in Egypt between two years, 1998 and 2006, and gives a brief description of the career movements that occurred among the whole group in terms of job security and wages. The target group is individuals who were 18 years old or above in 1998 and were no older than 64 years in 2006, with an intermediate or above degree, and who were waged workers in 1998 or 2006.

\subsubsection{Status Mobility between 1998 and 2006}

Tables II and 12 display the status of the panel group between 1998 and 2006. It is clear that the employment status distribution did not differ between 1998 and 2006 among either males or females. Females were less likely to remain waged workers than males (81.5\% vs. $86.9 \%)$, with a probability of quitting the labor force of around Io\%, excluding retirement.

This percentage increases among non-waged females to around $45 \%$, i.e. females are more likely to quit a non-waged job than to quit a waged one. In analyzing the initial wages and job security index of females who remained waged and who become non-waged, unemployed, or housewives 5 , Figure 2 illustrates that they had lower job security at the beginning and hence they had greater chances of quitting work or losing their jobs than those who had high job security.

Figure 3 displays the wages in 1998 for those who remained waged and those who transitioned to other statuses. The initial wages of women who left waged work $t$ were lower than those who remained waged. The wage differences among males are not as large as those among females.

5 Retired individuals were excluded as they are expected to have high wage and job security. 
Table 11: Employment Status Transitions between 1998 and 2006; Males Aged 26-64 in 2006 and $18-56$ in 1998 by Percent

\begin{tabular}{|l|c|c|c|c|c|c|c|}
\hline \multicolumn{1}{|c|}{ Status 06 } & Waged & $\begin{array}{c}\text { Non- } \\
\text { Waged }\end{array}$ & Unemployed & Retired & Other & $\begin{array}{c}\text { Row } \\
\text { Totals }\end{array}$ & $\begin{array}{c}\text { Distribution } \\
\text { in 1998 }\end{array}$ \\
\hline Waged & 86.9 & 5.68 & 0.85 & 5.81 & 0.72 & $100 \%$ & 72.77 \\
\hline Non-Waged & 25.56 & 68.13 & 1.16 & 2.66 & 2.5 & $100 \%$ & 17.66 \\
\hline Unemployed & 60.81 & 22.03 & 5.79 & 2.01 & 9.36 & $100 \%$ & 1.6 \\
\hline Retired & 6.37 & 0 & 0 & 84.58 & 9.05 & $100 \%$ & 4.55 \\
\hline Student & 66.19 & 17.67 & 1.34 & 0 & 14.8 & $100 \%$ & 3.39 \\
\hline Distr. in 06 & 72.82 & 17.39 & 1.39 & 4.8 & 3.58 & & $100 \%$ \\
\hline
\end{tabular}

Source: Based on author's calculations from ELMS and ELMPS

Table 12: Employment Status Transitions between 1998 and 2006; Females Aged 26-64 in 2006 and $18-56$ in 1998 by Percent

\begin{tabular}{|l|c|c|c|c|c|c|c|c|c|}
\hline \multicolumn{1}{|c|}{$\begin{array}{c}\text { Status } \\
2006\end{array}$} & Waged & $\begin{array}{c}\text { Non- } \\
\text { Waged }\end{array}$ & Unemployed & $\begin{array}{c}\text { House } \\
\text { wife }\end{array}$ & $\begin{array}{c}\text { Leave } \\
\text { for } \\
\text { Child } \\
\text { Care }\end{array}$ & Retired & 0ther & $\begin{array}{c}\text { Row } \\
\text { Totals }\end{array}$ & $\begin{array}{c}\text { Distribution } \\
\text { in 1998 }\end{array}$ \\
\hline Waged & 81.51 & 0.56 & 1.02 & 7.48 & 0.97 & 6.3 & 2.16 & $100 \%$ & 41.73 \\
\hline Non-Waged & 15.87 & 39.51 & 0 & 38.42 & 0 & 0 & 6.19 & $100 \%$ & 2.24 \\
\hline Unemployed & 13.77 & 2.49 & 2.04 & 63.66 & 0.94 & 0 & 17.09 & $100 \%$ & 0.95 \\
\hline Housewife & 8.87 & 3.36 & 0.54 & 77.18 & 0.31 & 1.34 & 8.39 & $100 \%$ & 42.42 \\
\hline leave & 61.85 & 0 & 0 & 30.35 & 7.8 & 0 & 0 & $100 \%$ & 0.88 \\
\hline Retired & 0 & 0 & 0 & 36.95 & 0 & 63.05 & 0 & $100 \%$ & 3.05 \\
\hline Student & 29.72 & 0.26 & 0.31 & 46.18 & 1.01 & 0 & 22.51 & $100 \%$ & 8.72 \\
\hline Distr. in 06 & 41.71 & 2.27 & 0.96 & 42.34 & 0.89 & 3.08 & 8.75 & & $100 \%$ \\
\hline
\end{tabular}

Source: Based on author's calculations from ELMS and ELMPS 
Figure 1: Job Security Index Distribution of Waged Workers in 1998 by Current Status, by Gender, Age 26-64

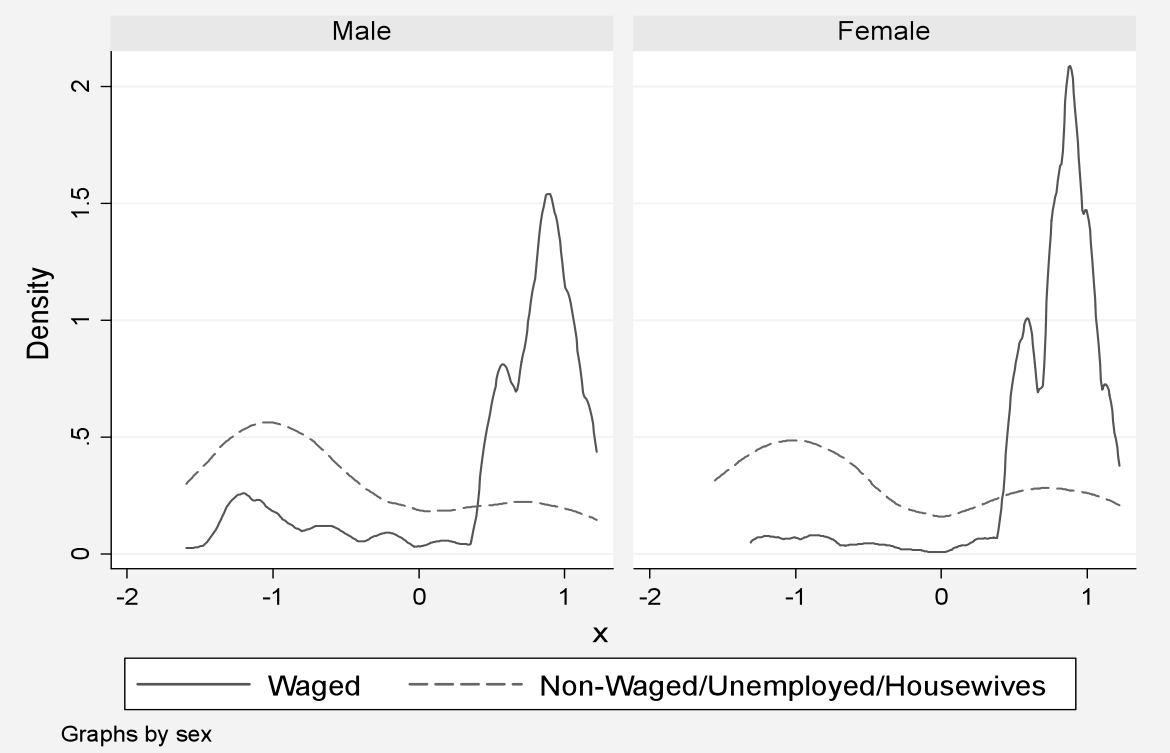

Figure 2: Log Hourly Wage Distribution of Waged Workers in 1998 by Current Status, by Gender, Age 26-64

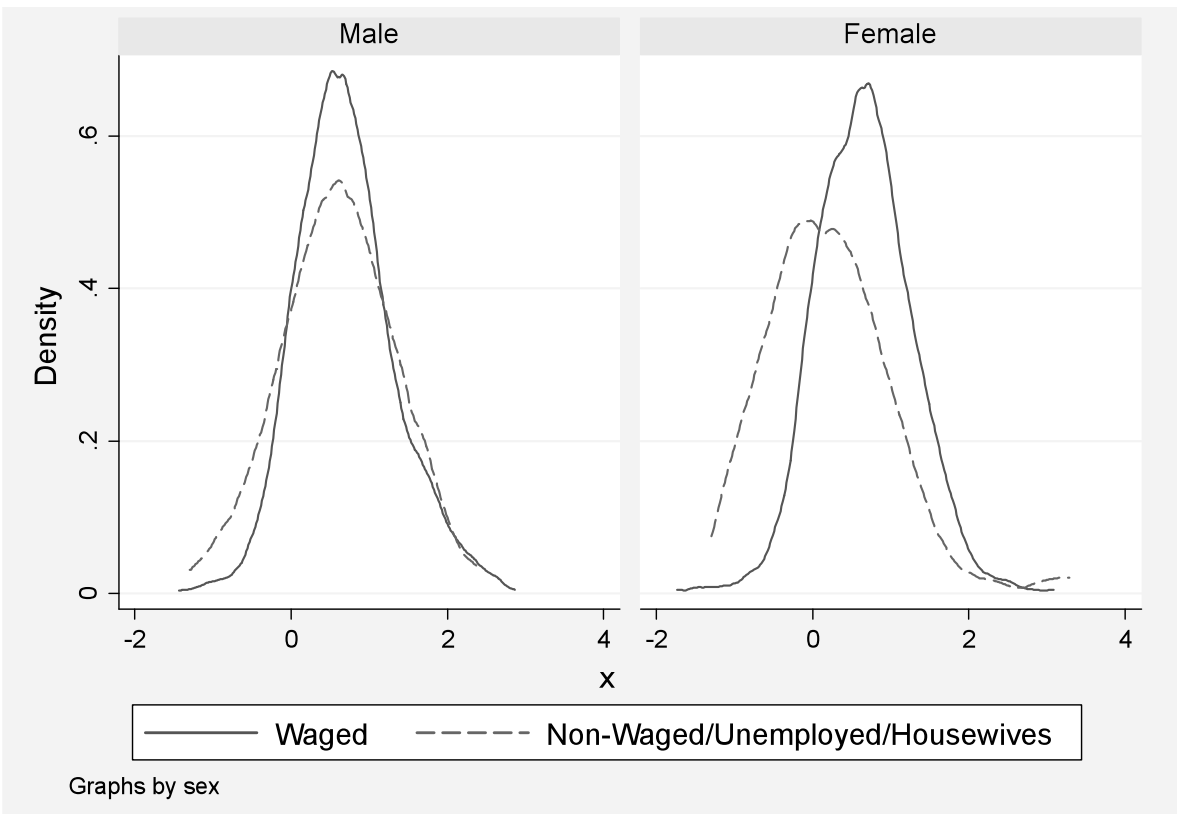

Source: Based on author's calculations from ELMS and ELMPS 


\subsubsection{Job Security Mobility ${ }^{6}$ between 1998 and 2006}

\section{Mobility Direction}

For those who were waged in 1998 and remained waged in 2006 , there is a slight improvement in job security distribution in general, with a slightly higher improvement among females aged $26^{-} 4 \mathrm{O}$ and $4 \mathrm{I}^{-} 64$ than males of the same age groups, as shown in Figures 3 and 4.

About one third of the target population, both male and female, suffered from an absolute decrease in the job security index between 1998 and 2006 (see Table i3).

To study the position improvement of the target population, the quartile rank was computed in 1998 for all those aged $18-56$ (even if not within the panel) and in 2006 for those aged 26-64 (even if not within the panel). ${ }^{7}$

Figure 3: Job Security Index Distribution in 1998 and 2006 by Gender, Age 26-40

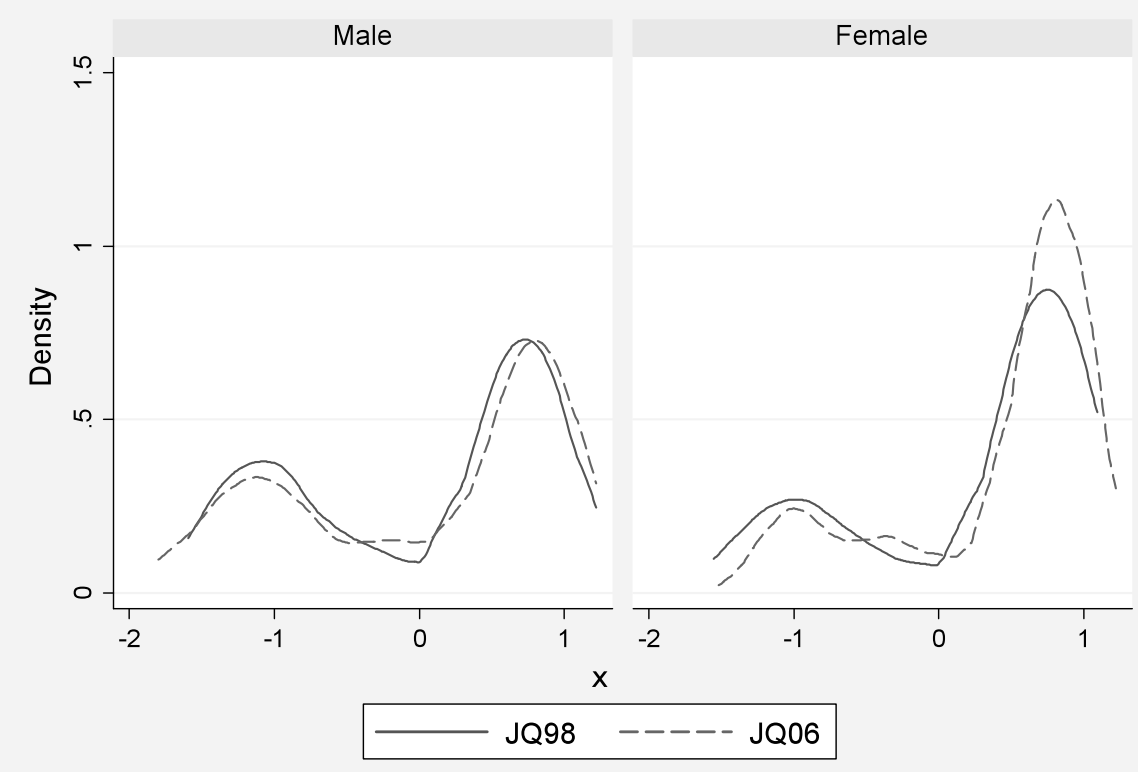

Graphs by sex

6 Job security indices were based on the same variables mentioned above and were calculated for the pooled sample in order to have same variable weights in both years.

7 The reasons for this are to avoid the effect of youth insertion in 2006 and to observe the normal career path. 
Figure 4: Job Security Index Distribution in 1998 and 2006 by Gender, Age 41-64

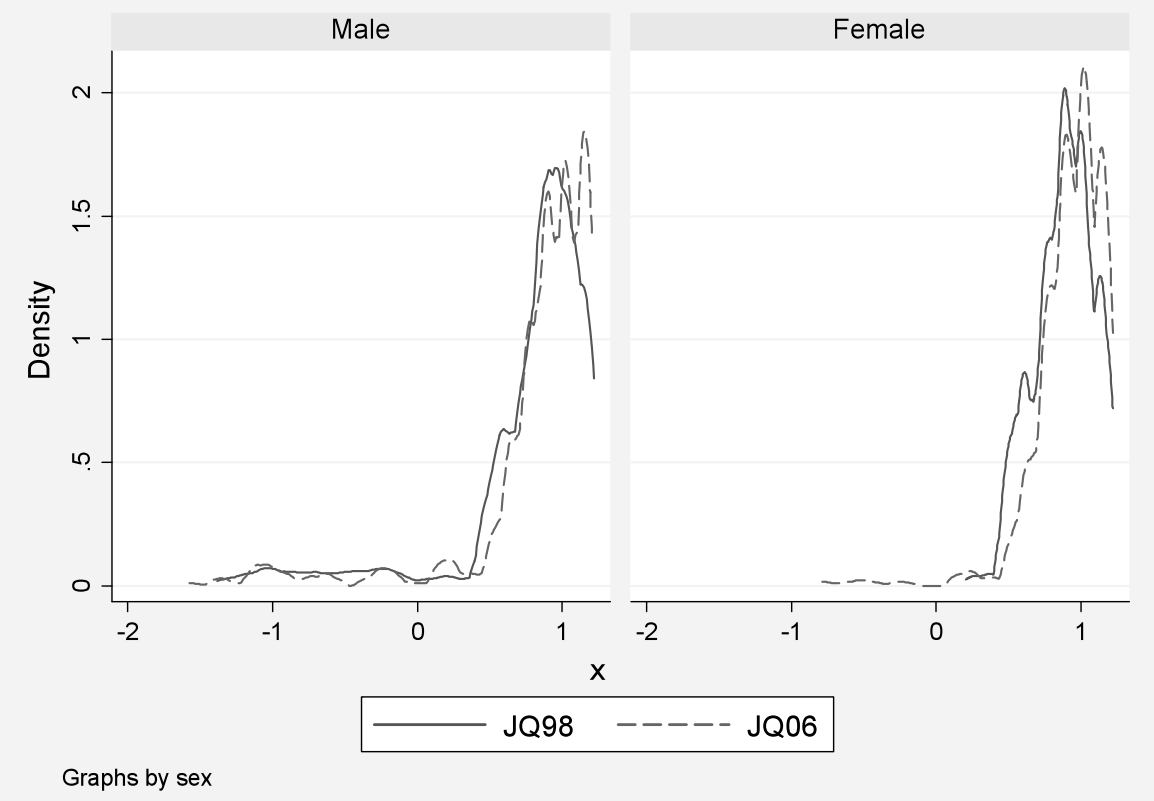

Source: Based on author's calculations from ELMS and ELMPS

Table 13: Job Security Index Value Transitions between 1998 and 2006, by Gender, Age 26-64 by Percent

\begin{tabular}{|l|c|c|c|}
\hline Job Security & Male & Female & Total \\
\hline Downward & 30.7 & 28.1 & 29.8 \\
\hline Stable & 11.1 & 11.4 & 11.2 \\
\hline Upward & 58.2 & 60.5 & 59.0 \\
\hline Column Total & $100 \%$ & $100 \%$ & $100 \%$ \\
\hline
\end{tabular}

Table 14: Job Security Index Rank Transition between 1998 and 2006, Males Age 26-64 by Percent

\begin{tabular}{|c|c|c|c|c|c|c|}
\hline \multirow{2}{*}{$\begin{array}{c}1998 \\
\text { Quartile }\end{array}$} & $\mathbf{1}$ & $\mathbf{2}$ & $\mathbf{3}$ & $\mathbf{4}$ & $\begin{array}{c}\text { Row } \\
\text { Total }\end{array}$ & \multirow{2}{*}{ Dist. In 1998 } \\
\cline { 2 - 6 } & $\mathbf{5 1 . 3}$ & 26.3 & 10.0 & 12.4 & $100 \%$ & $21.4 \%$ \\
\hline $\mathbf{1}$ & 4.6 & 30.6 & 22.8 & 42.0 & $100 \%$ & $28.1 \%$ \\
\hline 2 & 1.4 & 26.6 & 24.7 & 47.3 & $100 \%$ & $20.6 \%$ \\
\hline 3 & 1.8 & 10.7 & 20.0 & 67.5 & $100 \%$ & $29.9 \%$ \\
\hline 4 & 13.1 & 22.9 & 19.6 & 44.4 & $100 \%$ & \\
\hline Dist. in 2006 & & & & & \\
\hline
\end{tabular}


Table 15: Job Security Index Rank Transition between 1998 and 2006, Females Age 26-64 by Percent

\begin{tabular}{|c|c|c|c|c|c|c|}
\hline \multirow{2}{*}{$\begin{array}{c}1998 \\
\text { Quartile }\end{array}$} & \multicolumn{4}{|c|}{2006 Quartile } & \multirow[b]{2}{*}{$\begin{array}{l}\text { Row } \\
\text { Total }\end{array}$} & \multirow[b]{2}{*}{ Dist. In 1998} \\
\hline & 1 & 2 & 3 & 4 & & \\
\hline 1 & 52.0 & 24.9 & 17.0 & 6.1 & $100 \%$ & $9.5 \%$ \\
\hline 2 & 0.6 & 34.0 & 23.2 & 42.2 & $100 \%$ & $36.0 \%$ \\
\hline 3 & 0.9 & 29.2 & 20.1 & 49.9 & $100 \%$ & $23.5 \%$ \\
\hline 4 & 0.5 & 12.4 & 19.3 & 67.8 & $100 \%$ & $31.0 \%$ \\
\hline Dist. in 2006 & 5.6 & 25.3 & 20.7 & 48.5 & $100 \% \%$ & \\
\hline
\end{tabular}

Source: Based on author's calculations from ELMS and ELMPS

In Tables I4 and 15 , the percentage of females in the lowest quartiles compared to males is low, indicating again the preference among women to quit the labor market rather than to maintain an insecure job. Figure 5 indicates that those with low job security are more likely to move upward, those with high job security maintain their secure jobs, and those in the middle are at risk of losing some of their job security.

Generally, there are more individuals who move upward and improve their positions than those who move downward or worsen their positions. ${ }^{8}$

Figure 5: Median Job Security Index by Transition Direction in 1998 and 2006, by Gender, Age 26-64

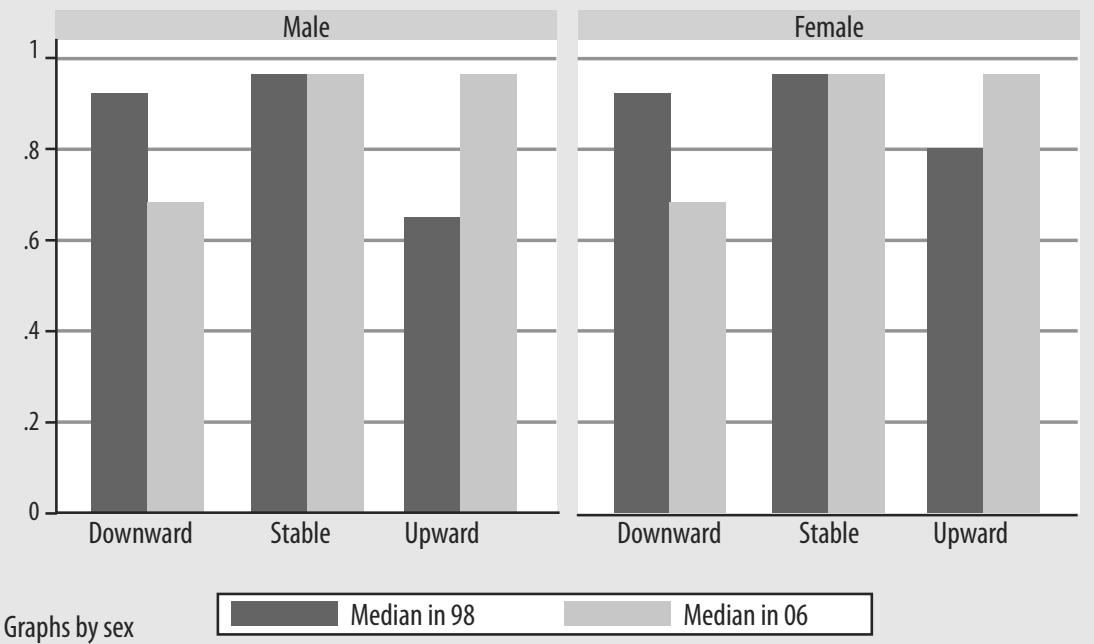

Source: Based on author's calculations from ELMS and ELMPS

8 Note that the quartile's values were based on the whole sample in each year, therefore the percentages are not $25 \%$. 


\subsubsection{Wage Mobility between 1998 and 2006}

\section{Mobility Direction}

Table 16: Wage Transition Direction between 1998 and 2006 by Gender, Age 26-64 by Percent

\begin{tabular}{|l|c|c|c|}
\hline Wage Mobility & Male & Female & Total \\
\hline Downward & 19.0 & 15.7 & 18.0 \\
\hline Stable & 3.6 & 3.4 & 3.5 \\
\hline Upward & 77.4 & 80.8 & 78.5 \\
\hline Column Total & $100 \%$ & $100 \%$ & $100 \%$ \\
\hline
\end{tabular}

Source: Based on author's calculations from ELMS and ELMPS

Between 1998 and 2006 only about one-fifth of waged workers were unable to gain a real increase in their hourly wages. As seen in the quartile transition in Table 17 , women have a higher probability of staying in the

lowest quartile of wages than of staying in a low security job. Comparing the quartile distributions in 1998 and 2006, the conclusion that those in the first wage or job security quartile are more likely to quit the waged status is confirmed.

Table 17: Hourly Wage Rank Transition between 1998 and 2006, Males Age 26-64 by Percent

\begin{tabular}{|c|c|c|c|c|c|c|}
\hline \multirow{2}{*}{$\begin{array}{c}1998 \\
\text { Quartile }\end{array}$} & \multicolumn{5}{|c|}{2006 Quartile } & \multirow{2}{*}{ Dist. In 1998 } \\
\cline { 2 - 6 } & 1 & 2 & 3 & 4 & $\begin{array}{c}\text { Row } \\
\text { Total }\end{array}$ & \\
\hline 1 & 35.7 & 34.5 & 17.9 & 11.9 & $100 \%$ & $26.7 \%$ \\
\hline 2 & 14.6 & 25.5 & 41.9 & 18.1 & $100 \%$ & $27.1 \%$ \\
\hline 3 & 7.1 & 26.5 & 30.3 & 36.1 & $100 \%$ & $23.4 \%$ \\
\hline 4 & 6.0 & 6.8 & 19.7 & 67.5 & $100 \%$ & $22.8 \%$ \\
\hline Total & 16.5 & 23.9 & 27.7 & 31.9 & $100 \%$ & \\
\hline
\end{tabular}

9 Note that the quartile's values were based on the whole sample in each year, therefore the percentages are not $25 \%$. 
Table 18: Hourly Wage Rank Transition between 1998 and 2006, Females Age 26-64 by Percent

\begin{tabular}{|c|c|c|c|c|c|c|}
\hline \multirow{2}{*}{$\begin{array}{c}1998 \\
\text { Quartile }\end{array}$} & \multicolumn{5}{|c|}{2006 Quartile } & \multirow{2}{*}{ Dist. In 1998 } \\
\cline { 2 - 6 } & $\mathbf{1}$ & $\mathbf{2}$ & $\mathbf{3}$ & $\mathbf{4}$ & $\begin{array}{c}\text { Row } \\
\text { Total }\end{array}$ & \\
\hline $\mathbf{1}$ & 33.7 & 33.8 & 16.6 & 15.8 & $100 \%$ & $27.6 \%$ \\
\hline $\mathbf{2}$ & 12.9 & 27.4 & 33.6 & 26.1 & $100 \%$ & $25.7 \%$ \\
\hline 3 & 3.7 & 17.0 & 43.9 & 35.5 & $100 \%$ & $25.9 \%$ \\
\hline 4 & 2.2 & 10.7 & 24.3 & 62.9 & $100 \%$ & $20.9 \%$ \\
\hline Total & 14.0 & 23.0 & 29.6 & 33.4 & $100 \%$ & \\
\hline
\end{tabular}

Source: Based on author's calculations from ELMS and ELMPS

Wage increases were mainly concentrated among the older group and those working in public sector. Only young women working in the private sector suffered from downward mobility, but they represent only about $7 \%$ of waged women.

Figure 6: Median Real Hourly Wages in 1998 and 2006, by Sector in 2006, by Gender and Age
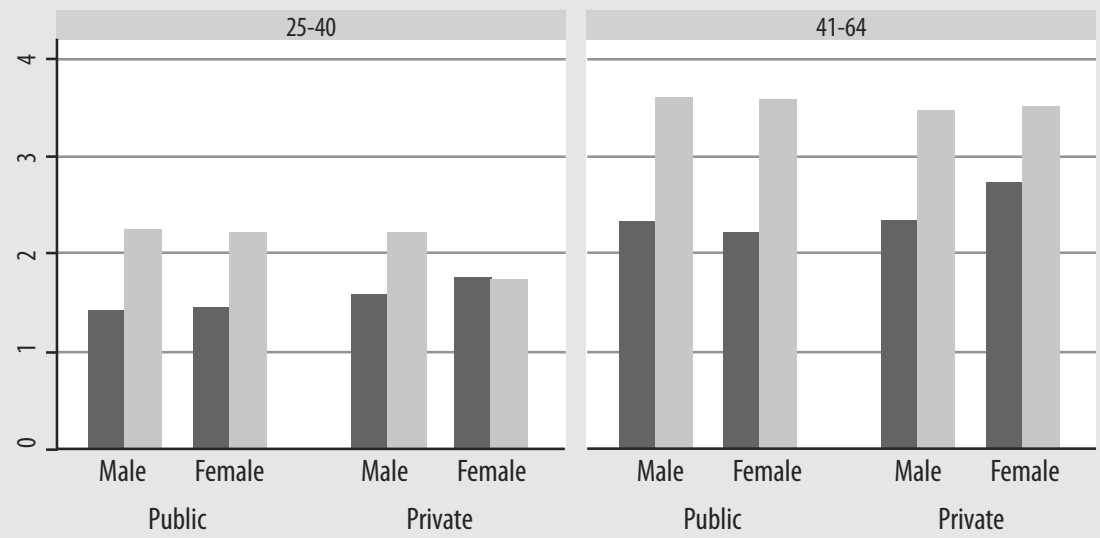

Graphs by agecat

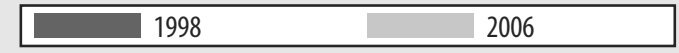

Source: Based on author's calculations from ELMS and ELMPS

\subsubsection{The Wage/ Security Tradeoff}

This section investigates the choice between wages and job security among males and females. More individuals were able to improve their wages than their job security. Slight differences appear by gender; while 
a higher percentage of females than males increased their wages, a higher percentage of males than females improved their job security.

Only around half of both males and females improved their career, in terms of both wages and job security.

Almost one-fifth of males and females succeeded in increasing their wages but worsened their job security in return. A lower percentage improved their job security (I6.6\% of males, $13.4 \%$ of females), but their hourly wages decreased e. Studying sector transitions might explain this tradeoff between job security and wage.

Around $8 \%$ of males and females failed to achieve any progress within a period of eight years, most of them ending up in a worse position, financially or in terms of job security.

Table 19: Wage / Security Tradeoff, Males age 26-45, Cell/ Total Percentage

\begin{tabular}{|l|c|c|c|c|}
\hline Male 26-45 & \multicolumn{4}{|c|}{ Job Security } \\
\hline Real Hourly Wage & Worse & Stable & Better & Total \\
\hline Worse & 5.96 & 1.11 & 9.55 & 16.62 \\
\hline Stable & 0.74 & 0.09 & 2.1 & 2.93 \\
\hline Better & 20.78 & 8.98 & 50.69 & 80.45 \\
\hline Total & 27.48 & 10.18 & 62.34 & $100 \%$ \\
\hline
\end{tabular}

Table 20: Wage / Security Tradeoff, Females age 26-45, Cell/Total Percentage

\begin{tabular}{|l|c|c|c|c|}
\hline Female 26-45 & \multicolumn{4}{|c|}{ Job Security } \\
\hline Real Hourly Wage & Worse & Stable & Better & Total \\
\hline Worse & 4.71 & 1.29 & 7.41 & 13.42 \\
\hline Stable & 0.73 & 0.7 & 2.08 & 3.51 \\
\hline Better & 21.79 & 10.48 & 50.8 & 83.07 \\
\hline Total & 27.23 & 12.48 & 60.29 & $100 \%$ \\
\hline
\end{tabular}

\section{Determining the Main Factors of Career Mobility by Gender}

\subsection{Multivariate Analysis}

For the second objective, multivariate analysis is applied separately for females and males. A bivariate probit model with double selection is suggested for females (Winship and Mare 1992, Bonnie 2008), considering that two decisions are taken, the first being whether to enter a waged work career and the second being whether to continue in the waged work career, where both decisions are subject to self-selection.

The main difference between men and women is that choice for women is mainly between being a waged worker or a housewife, as non-waged 
workers represent only $2.2 \%$ of the female target sample in 1998 (see Tableı2). In addition to the first choice, the status that females most likely switch to when they transition from waged status is again housewife; very few women quit waged work to become non-waged (0.6\%, see Table I2). For males, around $5.7 \%$ of waged workers switched to non-waged work.

Hence, the determinants of the first and second choices should differ by gender. Several actions are taken in the analysis to determine these factors:

-Students in 1998 are excluded from the analysis, since the main determinant of not working should be studying.

- The analysis is restricted to those aged 45 or under in order to reduce the probability of transitioning to retirement status, which has different determinants. This also allows us to focus on early career mobility instead of life career mobility. ${ }^{10}$

- Finally, the bivariate probit model with double selection is replaced with a Heckman model with a univariate probit selection equation. The main reason is the small number of those who quit waged work status, which prevents the convergence of the bivariate model with double selection.

\subsection{Methodology}

The wage or job security index change is observed only for those who joined the waged market in 1998 and decided to continue in it until 2006. Therefore it is assumed that an underlying regression relationship exists (Greene, 2008).

$$
y_{i}=x_{i} \beta+u_{1 i}
$$

Where the $y_{i}$ is the change in the log hourly wage (job security) and is only observed if

$$
\begin{aligned}
& w^{*}=z_{i} \gamma+u_{2 i}>0 \\
& u_{1 i} \sim N(0, \sigma) \\
& u_{2 i} \sim N(0,1) \\
& \operatorname{corr}\left(u_{1}, u_{2}\right)=\rho
\end{aligned}
$$

Where in our case the $w^{*}$ represents the utility of working as a waged worker from 1998 until 2006 and y is observed only if $w^{*}$ is greater than o; i.e. the individual becomes a waged worker. The $z$ is a vector of factors that influence the decision to become a waged worker.

10 Reducing the age to 40 caused problems in convergence because of the small number of observations. 
If the $\rho \neq 0$ then applying the ordinary least square regression will yield biased estimates.

Since only one decision is made here, the model is applied twice, first if only the decision of working as waged worker in 1998 is considered, i.e. regardless of whether the individual continued as waged worker or not.

The second model is applied only to those who started working in 1998 as waged workers and the selection equation was based on the decision to continue as a waged worker until 2006.

In order to identify whether both decisions - working as a waged worker and continuing in waged status are interrelated or not, the probit model with sample selection is applied as follows:

$$
\begin{gathered}
y_{1 i}^{*}=x_{1 i} \beta_{1}+u_{1 i} \\
y_{2 i}^{*}=x_{2 i} \beta_{2}+u_{2 i}
\end{gathered}
$$

Where the $y_{1}^{*}$ and $y_{2}^{*}$ are not observed and only the binary dependent variables are observed if

$$
y_{j}=\left\{\begin{array}{ll}
1 & y_{j}^{*}>0 \\
0 & y_{j}^{*} \leq 0
\end{array}\right\} \text { for } j=1,2
$$

If the two error terms are independent, two separate probit models can be applied, otherwise a probit with selection is preferable.

\subsection{Covariates}

\section{Individual Characteristics:}

Education and age are categorized as follows: age is divided into four categories of five-year intervals starting at 26. Education is categorized as intermediate level, above intermediate, and university and above.

\section{Life events:}

There are two major events in a woman's life that might influence her work decisions or career mobility, namely getting married and having children.

To avoid endogeneity, these variables are not considered in the males' analysis. For females, marital status in 1998 is expected to affect the first working decision, while getting married between 1998 and 2006 might affect the decision to continue working. As for having children, it is investigated whether taking maternity leave hinders a woman's career. The 
variable is investigated only in case of wage mobility and not job security mobility because of endogeneity. The maternity leave variable is a binary and, takes the value $o$ if no or less than three months of leave is taken, and I for maternity leave longer than three months.

\section{Job Mobility and Job Characteristics:}

One of the important factors that might be of interest is the effect of changing jobs on wage mobility (Perticara 2002, Davia 2005, Pavlopoulos et al. 2007, and Balzquez 2008). This is investigated by studying the effect of changing the job of 1998 on the wage and job security index.

Experience is measured by time since first joining the labor market and is included as a quadratic function in order to determine the impact of early entry in the labor market on wage and job security change.

Other job characteristics in 1998 were also considered:

Occupation: Professional, managerial, and technical fields were combined, clerks and sales were combined, and agriculture, fishing, and craft work were combined. For women, only the first two categories were considered, as there are almost no observations in the third category.

Sector: Being in the public or private sector in 1998 is considered as a factor in deciding whether to continue as a waged worker or not. Comparing wage mobility by sector is considered by adding the 2006 sector in the wage change equation.

2uality of the 1998 fob: The impact of the job quality of the 1998 job on deciding whether to continue as waged worker or not is studied. Job quality in terms of the job security index value and wage in 1998 were added as covariates in the continuing waged work equations. ${ }^{\text {II }}$

In order to investigate which group is more likely to gain a higher wage or greater security increase, the ranks of the job security index and wage in 1998 were added as covariates in the equations for wage and job security index change.

\section{Family Characteristics:}

Only the father's occupation and education were considered. Education variables are intermediate and above education, or university and above, versus low and no education as the reference category.

Father's occupation is categorized into four groups: professionals,

11 Variables are added as continuous rather than as ranks in order to decrease the number of covariates in these equations, because of the small number of observations who dropped out of waged status. 
managers and technicians combined, clerks and sales combined, agriculture and fishing combined, and crafts, trading, and elementary jobs combined.

Family Enterprise in 1998: Having a family project is investigated as a factor that may influence the decision of working as waged worker.

Wealth in 1998: The value of the wealth index ${ }^{12}$ is tested for having an effect on the decision to work as waged worker.

\section{Results}

\subsection{Whether or not to Continue as a Waged Worker}

This section provides a preliminary investigation of the determinants of changing the waged status for females and males using a probit model with selection. While women mainly choose between working and staying home, men choose between waged work and being a self- employed or an employer (less than $3 \%$ of working females fall into this category vs. $17 \%$ of working males). Hence factors of making decisions may differ.

Table 22 shows the marginal effect of the considered variable and the coefficients; the main interest at this point is recognizing the significant variables and their directions rather than measuring the magnitude of the effect.

Older, single and highly educated females have a higher probability of joining the waged labor market. If there is a family project, this decreases the probability, either of working for the family as unpaid worker, or of not working at all. High wealth index slightly ( $\mathrm{p}$-value=0.15) decreases the probability of waged work in the first model, but is significant in the remaining models for females.

Richer, older males have a higher probability of being waged workers. Having a family project or a father working in agriculture or fishing decreases this probability compared to working as non-waged worker.

Conditional on being waged in 1998 , three major factors influence a woman's decision to quit waged work status; poor wage in 1998 , poor job security in 1998 and finally getting married within this period.

For males, a low job security index and working as a clerk or in sales decreases the probability of remaining in waged work.

Applying the probit model with selection implies that there is no correlation between the error terms of the two equations and the rho is not significantly different from o, i.e. the two decisions are made separately.

12 Wealth index was constructed by the population council group and was used as it is. 


\subsection{Factors of Wage Increase}

The Heckman selection model is used twice for both males and females. Tables 24 and 25 show the results of applying the model when the selection equation is being a waged worker in 1998 or not. Tables 26 and 27 show the results when the selection equation is whether males and females continue as waged workers until 2006 or not...

Comparing the significance of the correlation coefficient of the error terms shows that for males, only the equations of the first model are significantly correlated, while in the second model they are not.

For females the correlation coefficient was significant in both models with moderate stability in the covariates' significance. The conclusions are restricted to the first model, since it has more observations, quick and stable convergence in case of females and the correlation coefficient is not significant in case of males in the second model. ${ }^{13}$

Age:

There is a significant linear relationship between age and wage increase for both males and females; older employees gain higher wage increases.

\section{Education:}

While for females obtaining an above intermediate or university degree results in greater wage increases than having only intermediate degree, for males the significant difference appears only if they have a university degree or higher.

\section{Occupation:}

Neither the occupation nor the sector the workers ended in 2006 had a significant effect on the wage increase.

\section{Fob security and wage rank in 1998 :}

Individuals in lower wage quartiles gain higher wage increases than those in higher quartiles.

In terms of job security, females with higher job security gained higher raises. For males, those who were in the third quartile gained higher raises compared to those in the first quartile. It must be noted here that the significance and direction of the effect of job security and wage rank among females do not differ in first and second models.

\section{Changing jobs:}

The effect of job mobility on wage change is studied by analyzing whether having the same job since 1998 has a negative or positive effect

13 Limdep 0.9 was used in the bivariate probit with double selection model, but due to the small number of observations that quit the waged market, the model failed to converge. 
on wage change. No significant effect of changing jobs on wage change appeared in the analyses.

\section{Experience:}

There is an indication of a significant quadratic relationship between years of experience since the first job and wage change, indicating that a high raise will be achieved after some time, close to the end of 20 years of working life.

Place of residence:

Males in urban areas gain higher wage increases than males in rural areas. As for females, there was no significant effect of the place of residence.

Finally, taking maternity leave during this period had a negative impact on women's wage increase, which raises the question of whether having children constrains women's career path, and to what extent.

\subsection{Factors of Job Security Increase}

Applying the Heckman selection model, either using a selection equation based on being waged in 1998 or continuing to be waged until 2006 implied that none of the error terms were correlated in any model. Hence, results are shown only for the case of selection based on being waged in 1998. Results show only one relevant conclusion; those who did not have job security gained more.

\section{Conclusions}

This paper examines career mobility and development of waged workers with an intermediate and above education degree in the Egyptian market.

The analysis explores job to job transition and the search for increasing job security through job turnover for both males and females. The wage increase achieved after eight years is analyzed by gender and the determinants of that increase are studied.

The main conclusions of the analyses are as follows:

- Youth start their working career with less secure jobs in order to improve the quality of their jobs by moving to another job. Although females start with higher job security than males, males and females 
who are at the bottom, keep trying to improve their work security by moving to a second and third job and from the private to the public sector.

- Young males and females who fail to get a job in the public sector end up with low security jobs.

- Low wages and low job security are the main reasons for a woman to quit working once she gets married.

- Taking maternity leave for more than three months has a negative impact on wage increases for women.

- There is a tradeoff between wage and job security among younger youth.

Waged workers' transitions in Egypt, especially those in the public sector, have a tendency towards systematic upward movement with welldefined promotions and wage increases. Hence, around $90 \%$ of waged women are in the public sector; they have the same type of career path. Males and females working in the private sector are in the worst condition, and since the private sector is expanding and is absorbing more of the new labor market entrants, additional studies should be conducted to observe the early career mobility in the private sector and to observe the tradeoff between wages and job security among those new entrants.

Table 21: Variables' Names in the Analyses

\begin{tabular}{|l|l|}
\hline Variables & Definition \\
\hline Age & \\
\hline agecat1 & 26-30 years (Reference) \\
\hline agecat2 & $31-35$ years \\
\hline agecat3 & $36-40$ years \\
\hline agecat4 & $41-45$ years \\
\hline & \\
\hline Education in 1998 & \\
\hline edu981 & Intermediate (Reference) \\
\hline edu982 & Above intermediate \\
\hline edu983 & University and above \\
\hline & \\
\hline Sector in 1998 & \\
\hline pubpriv98 & Public $=0 /$ Private $=1$ \\
\hline
\end{tabular}




\begin{tabular}{|c|c|}
\hline samejob & 0 if job 1998 and 2006 is the same, 1 otherwise \\
\hline exp1job & Time from first job given in 1998 until 1998 \\
\hline exp1job2 & Squared time from first job given 1998 till 1998 \\
\hline \multicolumn{2}{|l|}{ Occupation } \\
\hline prof1 & Professionals, managers, technicians \\
\hline prof2 & Clerks, and sales \\
\hline prof3 & Agriculture, fishing, and craft workers \\
\hline \multicolumn{2}{|c|}{ Marriage status } \\
\hline marr9806 & Married between 1998 and 2006 \\
\hline preginterr & 1 if has taken maternity leave for more than 3 months, 0 otherwise \\
\hline marr98 & Married in 1998 \\
\hline \multicolumn{2}{|c|}{ Job Security Index } \\
\hline jsdiff* & Job Security Index difference between 2006 and 1998 \\
\hline fact98 & Job Security Index value in 1998 \\
\hline js981 & $\begin{array}{l}1 \text { if in first quartile of Job Security Index in 1998, } 0 \text { otherwise } \\
\text { (Reference) }\end{array}$ \\
\hline js982 & 1 if in second quartile of Job Security Index in 1998, 0 otherwise. \\
\hline js983 & 1 if in third quartile of Job Security Index in 1998,0 otherwise \\
\hline js984 & 1 if in fourth quartile of Job Security Index in 1998, 0 otherwise \\
\hline \multicolumn{2}{|l|}{ Wage } \\
\hline wage $98^{*}$ & 1 if was a wage worker in 1998, 0 otherwise \\
\hline Wagecont* & $\begin{array}{l}1 \text { if was wage worker in } 1998 \text { and continued to be in 2006, } 0 \\
\text { otherwise }\end{array}$ \\
\hline difflhwage $^{*}$ & Difference of log hourly real wage in 2006 and 1998 \\
\hline wg981 & 1 if in first wage quartile in 1998, 0 otherwise (Reference) \\
\hline wg982 & 1 if in second wage quartile in 1998,0 otherwise \\
\hline wg983 & 1 if in third wage quartile in 1998,0 otherwise \\
\hline wg984 & 1 if being in fourth quartile of wage in 1998,0 otherwise \\
\hline
\end{tabular}




\begin{tabular}{|c|c|}
\hline Family Characteristics & \\
\hline wealth98 & Wealth Index value in 1998 (based on family assets ) \\
\hline proj98 & 1 if family has a business in 1998, 0 otherwise \\
\hline urban98 & 1 if residence in 1998 was urban, 0 for rural \\
\hline $\begin{array}{l}\text { fathedu061 \& } \\
\text { fathedu062 }\end{array}$ & 1 if father has no or low education, 0 otherwise (Reference) \\
\hline fathedu063 & 1 if father's education is intermediate or above 0 otherwise \\
\hline fathedu064 & 1 if father's education is university or above, 0 otherwise \\
\hline fathocc4gr1 & $\begin{array}{l}1 \text { if father's occupation professionals managerial, or technical , } 0 \\
\text { otherwise (Reference) }\end{array}$ \\
\hline fathocc4gr2 & 1 if father's occupation clerical or sales, 0 otherwise \\
\hline fathocc4gr3 & 1 if father's occupation in agriculture or fishing, 0 otherwise \\
\hline fathocc $4 \mathrm{gr} 4$ & $\begin{array}{l}1 \text { if father's occupation in crafts, trading, or elementary jobs, } 0 \\
\text { otherwise }\end{array}$ \\
\hline
\end{tabular}

* These variables were used as dependent variables.

Table 22: Marginal Effects Probit with selection model, for females continuing to be waged workers in 2006, conditional on being a waged worker in 1998

\begin{tabular}{|l|c|c|c|c|}
\hline & $\begin{array}{c}\text { (1) Marginal } \\
\text { effect }\end{array}$ & (2) Coefficient & (3) Coefficient & (4) \\
\hline VARIABLES & $\begin{array}{c}\text { wagecont } \\
\text { wage98 }\end{array}$ & wagecont & wage98 & athrho \\
\hline agecat2 & 0.0287 & 0.0998 & $0.637^{* * *}$ & \\
\hline & $(0.110)$ & $(0.355)$ & $(0.154)$ & \\
\hline agecat3 & 0.173 & 0.698 & $1.422^{* * *}$ & \\
\hline & $(0.193)$ & $(0.489)$ & $(0.178)$ & \\
\hline agecat4 & 0.238 & $1.061^{*}$ & $2.029^{* * *}$ & \\
\hline & $(0.239)$ & $(0.591)$ & $(0.191)$ & \\
\hline edu982 & 0.0636 & 0.232 & $0.671^{* * *}$ & \\
\hline & $(0.116)$ & $(0.363)$ & $(0.135)$ & \\
\hline edu983 & 0.00437 & 0.0150 & $0.832^{* * *}$ & \\
\hline & $(0.111)$ & $(0.376)$ & $(0.132)$ & \\
\hline
\end{tabular}




\begin{tabular}{|c|c|c|c|c|}
\hline \multirow[t]{2}{*}{ pubpriv98 } & -0.0479 & -0.164 & & \\
\hline & $(0.101)$ & $(0.342)$ & & \\
\hline \multirow[t]{2}{*}{ marr9806 } & $-0.151^{*}$ & -0.472 & & \\
\hline & $(0.0913)$ & $(0.364)$ & & \\
\hline \multirow[t]{2}{*}{ rlnhw98 } & $0.140^{* *}$ & $0.477^{* *}$ & & \\
\hline & $(0.0699)$ & $(0.235)$ & & \\
\hline \multirow[t]{2}{*}{ fact98 } & $0.155^{* *}$ & $0.530^{* *}$ & & \\
\hline & $(0.0746)$ & $(0.218)$ & & \\
\hline \multirow[t]{2}{*}{ exp1job } & -0.00437 & -0.0149 & & \\
\hline & $(0.00400)$ & $(0.0134)$ & & \\
\hline \multirow[t]{2}{*}{ marr98 } & 0 & & $-0.798^{* * *}$ & \\
\hline & (0) & & (0.139) & \\
\hline \multirow[t]{2}{*}{ wealth } & 0 & & -0.141 & \\
\hline & (0) & & $(0.0979)$ & \\
\hline \multirow[t]{2}{*}{ proj98 } & 0 & & $-0.572^{* * *}$ & \\
\hline & $(0)$ & & $(0.110)$ & \\
\hline \multirow[t]{2}{*}{ urban98 } & 0 & & -0.194 & \\
\hline & $(0)$ & & $(0.124)$ & \\
\hline \multirow[t]{2}{*}{ fathedu063 } & 0 & & -0.0707 & \\
\hline & $(0)$ & & $(0.173)$ & \\
\hline \multirow[t]{2}{*}{ fathedu064 } & 0 & & -0.178 & \\
\hline & $(0)$ & & $(0.178)$ & \\
\hline \multirow[t]{2}{*}{ fathocc4gr1 } & 0 & & 0.0216 & \\
\hline & (0) & & $(0.141)$ & \\
\hline \multirow[t]{2}{*}{ fathocc4gr2 } & 0 & & -0.140 & \\
\hline & (0) & & $(0.148)$ & \\
\hline \multirow[t]{2}{*}{ fathocc $4 \mathrm{gr} 3$} & 0 & & 0.0133 & \\
\hline & $(0)$ & & $(0.162)$ & \\
\hline \multirow[t]{2}{*}{ Constant } & & 0.226 & $-0.802^{* * *}$ & 0.546 \\
\hline & & $(1.072)$ & $(0.164)$ & $(0.543)$ \\
\hline Observations & 927 & 927 & 927 & 927 \\
\hline Model Chi2 test & 77.00 & & & \\
\hline
\end{tabular}




\begin{tabular}{|l|c|l|l|l|}
\hline$p$-value & 0 & & & \\
\hline $\begin{array}{l}\text { Chi2 test for } \\
\text { comparison }\end{array}$ & 0.915 & & & \\
\hline$p$-value & 0.339 & & & \\
\hline rho & 0.497 & & & \\
\hline $\begin{array}{l}\text { Censored } \\
\text { Observations }\end{array}$ & 609 & & & \\
\hline
\end{tabular}

Standard errors in parentheses

${ }^{* * *} p<0.01,{ }^{* *} p<0.05,{ }^{*} p<0.1$

Table 23: Marginal Effects Probit with selection model, for males continuing to be waged workers in 2006, conditional on being a waged worker in 1998

\begin{tabular}{|l|c|c|c|c|}
\hline & $\begin{array}{c}\text { (1) Marginal } \\
\text { effect }\end{array}$ & (2) Coef & (3) Coef & (4) \\
\hline VARIABLES & $\begin{array}{c}\text { wagecont } \\
\text { wage98 }\end{array}$ & wagecont & wage98 & athrho \\
\hline agecat2 & 0.0164 & 0.178 & $0.789^{* * *}$ & \\
\hline & $(0.0301)$ & $(0.310)$ & $(0.119)$ & \\
\hline agecat3 & -0.000826 & -0.00839 & $1.211^{* * *}$ & \\
\hline & $(0.0379)$ & $(0.385)$ & $(0.132)$ & \\
\hline agecat4 & -0.0105 & -0.102 & $1.699^{* * *}$ & \\
\hline & $(0.0483)$ & $(0.468)$ & $(0.144)$ & \\
\hline edu982 & -0.0241 & -0.216 & 0.155 & \\
\hline & $(0.0313)$ & $(0.246)$ & $(0.138)$ & \\
\hline edu983 & -0.00735 & -0.0728 & 0.112 & \\
\hline & $(0.0280)$ & $(0.270)$ & $(0.118)$ & \\
\hline pubpriv98 & 0.0518 & $0.528^{*}$ & & \\
\hline & $(0.0327)$ & $(0.276)$ & & \\
\hline prof2 & $-0.0469^{*}$ & $-0.479^{*}$ & & \\
\hline & $(0.0279)$ & $(0.256)$ & & \\
\hline prof3 & -0.0420 & -0.429 & & \\
\hline & $(0.0315)$ & $(0.295)$ & & \\
\hline rlnhw98 & -0.00927 & -0.0946 & & \\
\hline & $(0.0148)$ & $(0.149)$ & & \\
\hline & & & & \\
\hline
\end{tabular}




\begin{tabular}{|c|c|c|c|c|}
\hline \multirow[t]{2}{*}{ fact98 } & $0.0299^{*}$ & $0.305^{*}$ & & \\
\hline & $(0.0170)$ & $(0.157)$ & & \\
\hline \multirow[t]{2}{*}{ exp1job } & 0.000400 & 0.00408 & & \\
\hline & $(0.00215)$ & $(0.0221)$ & & \\
\hline \multirow[t]{2}{*}{ wealth } & 0 & & $0.121^{*}$ & \\
\hline & (0) & & $(0.0720)$ & \\
\hline \multirow[t]{2}{*}{ prj98 } & 0 & & $-1.010^{* * *}$ & \\
\hline & (0) & & $(0.0965)$ & \\
\hline \multirow[t]{2}{*}{ urban98 } & 0 & & -0.170 & \\
\hline & (0) & & $(0.116)$ & \\
\hline \multirow[t]{2}{*}{ fathedu3 } & 0 & & -0.156 & \\
\hline & (0) & & $(0.149)$ & \\
\hline \multirow[t]{2}{*}{ fathedu4 } & 0 & & 0.0294 & \\
\hline & (0) & & $(0.194)$ & \\
\hline \multirow[t]{2}{*}{ fathoccg1 } & 0 & & $-0.236^{*}$ & \\
\hline & (0) & & $(0.130)$ & \\
\hline \multirow[t]{2}{*}{ fathoccg2 } & 0 & & -0.110 & \\
\hline & (0) & & $(0.137)$ & \\
\hline \multirow[t]{2}{*}{ fathoccg3 } & 0 & & -0.165 & \\
\hline & (0) & & $(0.145)$ & \\
\hline \multirow[t]{2}{*}{ Constant } & & $1.620^{* * *}$ & -0.0233 & -0.260 \\
\hline & & $(0.464)$ & $(0.150)$ & $(0.338)$ \\
\hline Observations & 1010 & & & \\
\hline Model Chi2 test & 39.38 & & & \\
\hline$p$-value & 4.57e-05 & & & \\
\hline $\begin{array}{l}\text { Chi2 test for } \\
\text { comparison }\end{array}$ & 0.648 & & & \\
\hline $\mathrm{p}$-value & 0.421 & & & \\
\hline rho & -0.254 & & & \\
\hline $\begin{array}{l}\text { Censored } \\
\text { Observations }\end{array}$ & 430 & & & \\
\hline
\end{tabular}


Table 24: Heckman selection model for log wage difference for Females, conditional on being a waged worker in 1998

\begin{tabular}{|c|c|c|c|c|}
\hline & (1) $d y / d x$ & (2) coef. & (3) & (4) \\
\hline VARIABLES & difflhwage & wage98 & athrho & Insigma \\
\hline \multirow[t]{2}{*}{ agecat2 } & $0.362^{*}$ & $0.403^{* *}$ & & \\
\hline & $(0.199)$ & $(0.157)$ & & \\
\hline \multirow[t]{2}{*}{ agecat3 } & $1.170^{* * *}$ & $1.200^{* * *}$ & & \\
\hline & (0.196) & $(0.160)$ & & \\
\hline \multirow[t]{2}{*}{ agecat4 } & $1.638^{* * *}$ & $1.718^{* * *}$ & & \\
\hline & $(0.214)$ & $(0.165)$ & & \\
\hline \multirow[t]{2}{*}{ edu982 } & $0.720^{* * *}$ & $0.742^{* * *}$ & & \\
\hline & $(0.151)$ & $(0.129)$ & & \\
\hline \multirow[t]{2}{*}{ edu983 } & $0.794^{* * *}$ & $0.698^{* * *}$ & & \\
\hline & $(0.147)$ & $(0.118)$ & & \\
\hline \multirow[t]{2}{*}{ preginterr } & $-0.227^{*}$ & & & \\
\hline & $(0.122)$ & & & \\
\hline \multirow[t]{2}{*}{ pubpriv06 } & -0.0979 & & & \\
\hline & $(0.144)$ & & & \\
\hline \multirow[t]{2}{*}{ prof2 } & 0.0307 & & & \\
\hline & $(0.0843)$ & & & \\
\hline \multirow[t]{2}{*}{ js 982} & $0.359 * *$ & & & \\
\hline & $(0.147)$ & & & \\
\hline \multirow[t]{2}{*}{ js 983} & $0.397 * *$ & & & \\
\hline & $(0.162)$ & & & \\
\hline \multirow[t]{2}{*}{ js 984} & $0.553 * * *$ & & & \\
\hline & $(0.196)$ & & & \\
\hline \multirow[t]{2}{*}{ wa982 } & $-0.395 * * *$ & & & \\
\hline & $(0.0855)$ & & & \\
\hline \multirow[t]{2}{*}{ wa983 } & $-0.619 * * *$ & & & \\
\hline & $(0.111)$ & & & \\
\hline wa984 & $-1.168 * * *$ & & & \\
\hline
\end{tabular}




\begin{tabular}{|c|c|c|c|c|}
\hline & $(0.143)$ & & & \\
\hline \multirow[t]{2}{*}{ samejob } & -0.0594 & & & \\
\hline & $(0.114)$ & & & \\
\hline \multirow[t]{2}{*}{ exp1job } & -0.0447 & & & \\
\hline & $(0.0281)$ & & & \\
\hline \multirow[t]{2}{*}{ exp1job2 } & $0.00282 *$ & & & \\
\hline & $(0.00145)$ & & & \\
\hline \multirow[t]{2}{*}{ urban98 } & -0.135 & -0.141 & & \\
\hline & $(0.139)$ & $(0.118)$ & & \\
\hline \multirow[t]{2}{*}{ marr98 } & & $-0.226^{* *}$ & & \\
\hline & & $(0.0977)$ & & \\
\hline \multirow[t]{2}{*}{ wealth } & & $-0.153 * * *$ & & \\
\hline & & $(0.0542)$ & & \\
\hline \multirow[t]{2}{*}{ proj98 } & & -0.0799 & & \\
\hline & & $(0.0641)$ & & \\
\hline \multirow[t]{2}{*}{ fathedu063 } & & -0.0910 & & \\
\hline & & $(0.106)$ & & \\
\hline \multirow[t]{2}{*}{ fathedu064 } & & 0.0418 & & \\
\hline & & $(0.108)$ & & \\
\hline \multirow[t]{2}{*}{ fathocc4gr1 } & & -0.0871 & & \\
\hline & & $(0.0804)$ & & \\
\hline \multirow[t]{2}{*}{ fathocc4gr2 } & & $-0.217^{* *}$ & & \\
\hline & & $(0.0899)$ & & \\
\hline \multirow[t]{2}{*}{ fathocc4gr3 } & & -0.107 & & \\
\hline & & $(0.104)$ & & \\
\hline \multirow[t]{2}{*}{ Constant } & $-1.502^{* * *}$ & $-1.229 * * *$ & $2.619^{* * *}$ & $0.145^{* *}$ \\
\hline & $(0.271)$ & $(0.151)$ & $(0.340)$ & $(0.0577)$ \\
\hline Observations & 886 & & & \\
\hline Model Chi2 test & 190.5 & & & \\
\hline$p$-value & 0 & & & \\
\hline $\begin{array}{l}\text { Chi2 test for } \\
\text { comparison }\end{array}$ & 72.43 & & & \\
\hline
\end{tabular}




\begin{tabular}{l|c|l|l|l|}
\hline$p$-value & 0 & & & \\
\hline rho & 0.989 & & & \\
\hline $\begin{array}{l}\text { Censored } \\
\text { Observations }\end{array}$ & 609 & & & \\
\hline & & & & \\
\hline
\end{tabular}
Standard errors in parentheses

Table 25: Heckman selection model for log wage difference for Males, conditional on being a waged worker in 1998

\begin{tabular}{|c|c|c|c|c|}
\hline & (1) dy/dx & (2) coef. & (3) & (4) \\
\hline VARIABLES & difflhwage & wage98 & athrho & Insigma \\
\hline \multirow{2}{*}{ agecat2 } & $0.782^{* * *}$ & $0.803^{* * *}$ & & \\
\hline & $(0.136)$ & $(0.121)$ & & \\
\hline \multirow[t]{2}{*}{ agecat3 } & $1.081^{* * *}$ & $1.165^{* * * *}$ & & \\
\hline & $(0.156)$ & $(0.132)$ & & \\
\hline \multirow[t]{2}{*}{ agecat4 } & $1.221^{* * *}$ & $1.561^{* * *}$ & & \\
\hline & $(0.177)$ & $(0.143)$ & & \\
\hline \multirow[t]{2}{*}{ edu982 } & 0.121 & 0.0533 & & \\
\hline & $(0.114)$ & $(0.131)$ & & \\
\hline \multirow[t]{2}{*}{ edu983 } & $0.287^{* * *}$ & 0.172 & & \\
\hline & $(0.106)$ & $(0.108)$ & & \\
\hline \multirow[t]{2}{*}{ pubpriv06 } & -0.0790 & & & \\
\hline & $(0.0916)$ & & & \\
\hline \multirow[t]{2}{*}{ prof2 } & 0.0766 & & & \\
\hline & $(0.0889)$ & & & \\
\hline \multirow[t]{2}{*}{ prof3 } & -0.0225 & & & \\
\hline & $(0.115)$ & & & \\
\hline \multirow[t]{2}{*}{ js982 } & 0.104 & & & \\
\hline & $(0.103)$ & & & \\
\hline \multirow[t]{2}{*}{ js983 } & $0.261^{* *}$ & & & \\
\hline & $(0.118)$ & & & \\
\hline js984 & 0.135 & & & \\
\hline
\end{tabular}




\begin{tabular}{|l|c|l|l|l|}
\hline & $(0.132)$ & & & \\
\hline wg982 & $-0.283^{* * *}$ & & & \\
\hline & $(0.0738)$ & & & \\
\hline wg983 & $-0.566^{* * *}$ & & & \\
\hline & $(0.0847)$ & & & \\
\hline wg984 & $-1.091^{* * *}$ & & & \\
\hline & $(0.108)$ & & & \\
\hline samejob & -0.00100 & & & \\
\hline & $(0.0745)$ & & & \\
\hline exp1job & $-0.0386^{* *}$ & & & \\
\hline & $(0.0172)$ & & & \\
\hline exp1job2 & $0.00175^{* * *}$ & & & \\
\hline & $(0.000635)$ & & & \\
\hline urban98 & $0.265^{* * *}$ & -0.0283 & & \\
\hline & $(0.0840)$ & $(0.107)$ & & \\
\hline wealth & & -0.0127 & & \\
\hline & & $(0.0554)$ & & \\
\hline prj98 & & $-0.606^{* * *}$ & & \\
\hline & & $(0.0897)$ & & \\
\hline fathedu3 & & -0.139 & & \\
\hline & & $(0.116)$ & & \\
\hline fathedu4 & & $0.249^{*}$ & & \\
\hline & & $(0.143)$ & & \\
\hline fathoccg1 & & $-0.233^{* *}$ & & \\
\hline & & $(0.0996)$ & & \\
\hline fathoccg2 & & -0.0117 & & \\
\hline & & $-0.191)$ & & \\
\hline fathoccg3 & & $(0.140)$ & \\
\hline & & & & \\
\hline Constant & & & \\
\hline & & & \\
\hline & & & \\
\hline
\end{tabular}




\begin{tabular}{|l|l|l|l|l|}
\hline Observations & 958 & & & \\
\hline Model Chi2 test & 224.8 & & & \\
\hline p-value & 0 & & & \\
\hline $\begin{array}{l}\text { Chi2 test for } \\
\text { comparison }\end{array}$ & 35.62 & & & \\
\hline p-value & $2.40 \mathrm{e}-09$ & & & \\
\hline rho & 0.920 & & & \\
\hline $\begin{array}{l}\text { Censored } \\
\text { Observations }\end{array}$ & 430 & & $* * * p<0.01,{ }^{* *} p<0.05,{ }^{*} p<0.1$
\end{tabular}

Table 26: Heckman selection model for log wage difference for Females, conditional on continuing as a waged worker in 2006

\begin{tabular}{|l|c|c|c|c|}
\hline & $(1)$ dy/dx & (2)coef. & (3) & (4) \\
\hline VARIABLES & difflhwage & wagecont & athrho & Insigma \\
\hline agecat2 & -0.0827 & 0.194 & & \\
\hline & $(0.186)$ & $(0.320)$ & & \\
\hline agecat3 & $0.440^{* *}$ & 0.459 & & \\
\hline & $(0.189)$ & $(0.394)$ & & \\
\hline agecat4 & $0.506^{* *}$ & $0.846^{* *}$ & & \\
\hline & $(0.212)$ & $(0.404)$ & & \\
\hline edu982 & $0.346^{* *}$ & 0.0676 & & \\
\hline & $(0.138)$ & $(0.310)$ & & \\
\hline edu983 & 0.210 & $-0.524^{* * *}$ & & \\
\hline & $(0.142)$ & $(0.179)$ & & \\
\hline preginterr & -0.193 & & & \\
\hline & $(0.167)$ & & & \\
\hline prof2 & -0.0201 & & & \\
\hline & $(0.107)$ & & & \\
\hline j5982 & $0.543^{* * *}$ & & & \\
\hline & $(0.154)$ & & & \\
\hline j5983 & $0.540^{* * *}$ & & & \\
\hline & $(0.163)$ & & & \\
\hline
\end{tabular}




\begin{tabular}{|c|c|c|c|c|}
\hline \multirow[t]{2}{*}{ js984 } & $0.642^{* * *}$ & & & \\
\hline & $(0.205)$ & & & \\
\hline \multirow[t]{2}{*}{ wa982 } & $-0.329 * * *$ & & & \\
\hline & $(0.116)$ & & & \\
\hline \multirow[t]{2}{*}{ wa983 } & $-0.518^{* * *}$ & & & \\
\hline & $(0.138)$ & & & \\
\hline \multirow[t]{2}{*}{ wa984 } & $-0.875^{* * *}$ & & & \\
\hline & $(0.183)$ & & & \\
\hline \multirow[t]{2}{*}{ samejob } & -0.141 & & & \\
\hline & $(0.108)$ & & & \\
\hline \multirow[t]{2}{*}{ exp1job } & 0.00580 & & & \\
\hline & $(0.0172)$ & & & \\
\hline \multirow[t]{2}{*}{ exp1job2 } & $2.20 \mathrm{e}-05$ & & & \\
\hline & $(0.000174)$ & & & \\
\hline \multirow[t]{2}{*}{ urban98 } & $-0.255^{* *}$ & -0.0688 & & \\
\hline & $(0.129)$ & $(0.202)$ & & \\
\hline \multirow[t]{2}{*}{ marr9806 } & & $-0.533^{*}$ & & \\
\hline & & $(0.273)$ & & \\
\hline \multirow[t]{2}{*}{ rlnhw98 } & & $0.352^{* * *}$ & & \\
\hline & & $(0.124)$ & & \\
\hline \multirow[t]{2}{*}{ fact98 } & & 0.127 & & \\
\hline & & $(0.128)$ & & \\
\hline \multirow[t]{2}{*}{ Constant } & 0.164 & $0.757^{* * *}$ & 18.37 & $-0.156^{* * *}$ \\
\hline & $(0.211)$ & $(0.292)$ & $(432.5)$ & $(0.0417)$ \\
\hline Observations & 357 & & & \\
\hline Model Chi2 test & 96.32 & & & \\
\hline$p$-value & 0 & & & \\
\hline $\begin{array}{l}\text { Chi2 test for } \\
\text { comparison }\end{array}$ & 45.20 & & & \\
\hline$p$-value & 0 & & & \\
\hline rho & 1 & & & \\
\hline $\begin{array}{l}\text { Censored } \\
\text { Observations }\end{array}$ & 50 & & & \\
\hline
\end{tabular}


Table 27: Heckman selection model for log wage difference for Males, conditional on continuing as a waged worker in 2006

\begin{tabular}{|c|c|c|c|c|}
\hline & (1) $d y / d x$ & (2) coef. & (3) & (4) \\
\hline VARIABLES & difflhwage & wagecont & athrho & Insigma \\
\hline \multirow[t]{2}{*}{ agecat2 } & 0.0819 & $0.365^{*}$ & & \\
\hline & $(0.122)$ & $(0.221)$ & & \\
\hline \multirow[t]{2}{*}{ agecat3 } & 0.207 & 0.271 & & \\
\hline & $(0.146)$ & $(0.245)$ & & \\
\hline \multirow[t]{2}{*}{ agecat4 } & 0.158 & 0.183 & & \\
\hline & $(0.170)$ & $(0.259)$ & & \\
\hline \multirow[t]{2}{*}{ edu982 } & -0.0256 & -0.136 & & \\
\hline & $(0.0974)$ & $(0.237)$ & & \\
\hline \multirow[t]{2}{*}{ edu983 } & 0.144 & 0.153 & & \\
\hline & $(0.0984)$ & $(0.221)$ & & \\
\hline \multirow[t]{2}{*}{ pubpriv06 } & -0.148 & & & \\
\hline & $(0.0979)$ & & & \\
\hline \multirow[t]{2}{*}{ prof2 } & 0.0535 & -0.219 & & \\
\hline & $(0.0913)$ & $(0.175)$ & & \\
\hline \multirow[t]{2}{*}{ prof3 } & -0.0334 & & & \\
\hline & $(0.117)$ & & & \\
\hline \multirow[t]{2}{*}{ js982 } & 0.143 & & & \\
\hline & $(0.110)$ & & & \\
\hline \multirow[t]{2}{*}{ js983 } & $0.343^{* * *}$ & & & \\
\hline & $(0.125)$ & & & \\
\hline \multirow[t]{2}{*}{ js984 } & $0.238^{*}$ & & & \\
\hline & $(0.139)$ & & & \\
\hline \multirow[t]{2}{*}{ wg982 } & $-0.346^{* * *}$ & & & \\
\hline & $(0.0800)$ & & & \\
\hline \multirow[t]{2}{*}{ wg983 } & $-0.608^{* * *}$ & & & \\
\hline & $(0.0916)$ & & & \\
\hline \multirow[t]{2}{*}{ wg984 } & $-1.062^{* * *}$ & & & \\
\hline & $(0.117)$ & & & \\
\hline samejob & -0.0523 & & & \\
\hline
\end{tabular}




\begin{tabular}{|c|c|c|c|c|}
\hline & $(0.0804)$ & & & \\
\hline \multirow[t]{2}{*}{ exp1job } & $-0.0591^{* * *}$ & & & \\
\hline & $(0.0199)$ & & & \\
\hline \multirow[t]{2}{*}{ exp1job2 } & $0.00255^{* * *}$ & & & \\
\hline & $(0.000737)$ & & & \\
\hline \multirow[t]{2}{*}{ urban98 } & $0.203^{* * *}$ & $-0.350^{*}$ & & \\
\hline & $(0.0744)$ & $(0.203)$ & & \\
\hline \multirow[t]{2}{*}{ rlnhw98 } & & -0.203 & & \\
\hline & & $(0.145)$ & & \\
\hline \multirow[t]{2}{*}{ fact98 } & & $0.643^{* * *}$ & & \\
\hline & & $(0.104)$ & & \\
\hline \multirow[t]{2}{*}{ Constant } & $0.844^{* * *}$ & $1.656^{* * *}$ & -0.181 & $-0.262^{* * *}$ \\
\hline & $(0.162)$ & $(0.250)$ & $(0.148)$ & $(0.0301)$ \\
\hline Observations & 627 & 627 & 627 & 627 \\
\hline Model Chi2 test & 125.7 & 125.7 & 125.7 & 125.7 \\
\hline$p$-value & 0 & 0.335 & 0 & 0.335 \\
\hline $\begin{array}{l}\text { Chi2 test for } \\
\text { comparison }\end{array}$ & 0.928 & 0.928 & 0.928 & 0.928 \\
\hline$p$-value & 0.335 & 0 & 0.335 & 0 \\
\hline rho & -0.179 & -0.179 & -0.179 & -0.179 \\
\hline $\begin{array}{l}\text { Censored } \\
\text { Observations }\end{array}$ & 54 & 54 & 54 & 54 \\
\hline
\end{tabular}

Table 28: Heckman selection model for Job Security change for Females, conditional on being a waged worker in 1998

\begin{tabular}{|l|c|c|c|c|}
\hline & (1) dy/dx & (2)coef. & (3) & (4) \\
\hline VARIABLES & jsdiff & wage98 & athrho & Insigma \\
\hline & & & & \\
\hline prof2 & 0.0374 & & & \\
\hline & $(0.0571)$ & & & \\
\hline agecat2 & -0.0766 & $0.609^{* * *}$ & & \\
\hline & $(0.0971)$ & $(0.172)$ & & \\
\hline
\end{tabular}




\begin{tabular}{|l|c|c|l|l|}
\hline agecat3 & 0.0824 & $1.526^{* * *}$ & & \\
\hline & $(0.108)$ & $(0.189)$ & & \\
\hline agecat4 & 0.141 & $2.153^{* *}$ & & \\
\hline & $(0.124)$ & $(0.200)$ & & \\
\hline edu982 & 0.000400 & $0.757^{* * *}$ & & \\
\hline & $(0.0669)$ & $(0.142)$ & & \\
\hline edu983 & 0.0996 & $0.891^{* * *}$ & & \\
\hline & $(0.0726)$ & $(0.139)$ & & \\
\hline j5982 & $-0.543^{* * *}$ & & & \\
\hline & $(0.0762)$ & & & \\
\hline js983 & $-0.718^{* * *}$ & & & \\
\hline & $(0.0835)$ & & & \\
\hline js984 & $-0.866^{* * *}$ & & & \\
\hline & $(0.0945)$ & & & \\
\hline wa982 & 0.0693 & & & \\
\hline & $(0.0529)$ & & & \\
\hline wa983 & 0.0667 & & & \\
\hline & $(0.0648)$ & & & \\
\hline wa984 & -0.0638 & & & \\
\hline & $(0.0850)$ & & & \\
\hline samejob & -0.0741 & & & \\
\hline & $(0.0580)$ & & & \\
\hline exp1job & 0.00209 & & & \\
\hline & $(0.0173)$ & & & \\
\hline exp1job2 & -0.000179 & & & \\
\hline & $(0.000907)$ & & & \\
\hline urban98 & 0.0122 & -0.0977 & & \\
\hline & $(0.0558)$ & $(0.133)$ & & \\
\hline marr98 & & $-0.589^{* * *}$ & & \\
\hline & & & & \\
\hline wealth & & & & \\
\hline & & & & \\
\hline
\end{tabular}




\begin{tabular}{|c|c|c|c|c|}
\hline \multirow[t]{2}{*}{ proj98 } & & $-0.476^{* * *}$ & & \\
\hline & & $(0.114)$ & & \\
\hline \multirow[t]{2}{*}{ fathedu063 } & & -0.0699 & & \\
\hline & & $(0.183)$ & & \\
\hline \multirow[t]{2}{*}{ fathedu064 } & & -0.139 & & \\
\hline & & $(0.188)$ & & \\
\hline \multirow[t]{2}{*}{ fathocc4gr1 } & & 0.0311 & & \\
\hline & & $(0.153)$ & & \\
\hline \multirow[t]{2}{*}{ fathocc4gr2 } & & -0.202 & & \\
\hline & & (0.158) & & \\
\hline \multirow[t]{2}{*}{ fathocc $4 \mathrm{gr} 3$} & & -0.0767 & & \\
\hline & & $(0.172)$ & & \\
\hline \multirow[t]{2}{*}{ Constant } & $0.605^{* * *}$ & $-1.156^{* * *}$ & 0.0520 & $-1.065^{* * *}$ \\
\hline & $(0.153)$ & $(0.181)$ & $(0.183)$ & $(0.0428)$ \\
\hline Observations & 887 & 887 & 887 & 887 \\
\hline Model Chi2 test & 127.0 & 127.0 & 127.0 & 127.0 \\
\hline $\mathrm{p}$-value & 0 & 0 & 0.781 & 0.781 \\
\hline $\begin{array}{l}\text { Chi2 test for } \\
\text { comparison }\end{array}$ & 0.0771 & 0.0771 & 0.0771 & 0.0771 \\
\hline$p$-value & 0.781 & 0.781 & 0 & 0 \\
\hline rho & 0.0519 & 0.0519 & 0.0519 & 0.0519 \\
\hline $\begin{array}{l}\text { Censored } \\
\text { Observations }\end{array}$ & 609 & 609 & 609 & 609 \\
\hline
\end{tabular}

Table 29: Heckman selection model for Job Security change for Males, conditional on being a waged worker in 1998

\begin{tabular}{|l|c|c|c|c|}
\hline & (1) $\mathrm{dy} / \mathrm{dx}$ & (2) coef. & (3) & (4) \\
\hline VARIABLES & jsdiff & wage98 & athrho & Insigma \\
\hline & & & & \\
\hline agecat2 & 0.0785 & $0.895^{* * *}$ & & \\
\hline & $(0.102)$ & $(0.126)$ & & \\
\hline agecat3 & 0.0932 & $1.347^{* * *}$ & & \\
\hline
\end{tabular}




\begin{tabular}{|l|c|c|l|l|}
\hline & $(0.123)$ & $(0.140)$ & & \\
\hline agecat4 & 0.168 & $1.856^{* * *}$ & & \\
\hline & $(0.144)$ & $(0.151)$ & & \\
\hline edu982 & 0.0605 & 0.163 & & \\
\hline & $(0.0675)$ & $(0.143)$ & & \\
\hline edu983 & $0.200^{* * *}$ & 0.190 & & \\
\hline & $(0.0672)$ & $(0.120)$ & & \\
\hline prof2 & 0.0342 & & & \\
\hline & $(0.0625)$ & & & \\
\hline prof3 & -0.113 & & & \\
\hline & $(0.0807)$ & & & \\
\hline js982 & $-0.605^{* * *}$ & & & \\
\hline & $(0.0656)$ & & & \\
\hline j5983 & $-0.852^{* * *}$ & & & \\
\hline & $(0.0776)$ & & & \\
\hline j5984 & $-0.948^{* * *}$ & & & \\
\hline & $(0.0853)$ & & & \\
\hline wg982 & 0.0209 & & & \\
\hline & $(0.0552)$ & & & \\
\hline wg983 & 0.0722 & & & \\
\hline & $(0.0630)$ & & & \\
\hline wg984 & -0.0838 & & & \\
\hline & $(0.0799)$ & & & \\
\hline samejob & -0.0146 & & & \\
\hline & $(0.0561)$ & & & \\
\hline exp1job & -0.0188 & & & \\
\hline & $(0.0136)$ & & & \\
\hline exp1job2 & 0.000664 & & & \\
\hline & $(0.000499)$ & & & \\
\hline urban98 & -0.0810 & & & \\
\hline & $(0.0511)$ & & & \\
\hline wealth & & & & \\
\hline & & & & \\
\hline prj98 & & & & \\
\hline & & & & \\
\hline
\end{tabular}




\begin{tabular}{|c|c|c|c|c|}
\hline \multirow[t]{2}{*}{ fathedu3 } & & -0.177 & & \\
\hline & & $(0.154)$ & & \\
\hline \multirow[t]{2}{*}{ fathedu4 } & & 0.111 & & \\
\hline & & $(0.198)$ & & \\
\hline \multirow[t]{2}{*}{ fathoccg1 } & & $-0.277^{* *}$ & & \\
\hline & & $(0.136)$ & & \\
\hline \multirow[t]{2}{*}{ fathoccg2 } & & -0.0660 & & \\
\hline & & $(0.142)$ & & \\
\hline \multirow[t]{2}{*}{ fathoccg3 } & & -0.208 & & \\
\hline & & $(0.152)$ & & \\
\hline \multirow[t]{2}{*}{ Constant } & $0.791^{* * *}$ & -0.163 & -0.201 & $-0.668^{* * *}$ \\
\hline & $(0.152)$ & $(0.159)$ & $(0.146)$ & $(0.0332)$ \\
\hline Observations & 958 & 958 & 958 & 958 \\
\hline Model Chi2 test & 219.4 & 219.4 & 219.4 & 219.4 \\
\hline$p$-value & 0 & 0 & 0 & 0 \\
\hline $\begin{array}{l}\text { Chi2 test for } \\
\text { comparison }\end{array}$ & 2.044 & 2.044 & 2.044 & 2.044 \\
\hline$p$-value & 0.153 & 0.153 & 0.153 & 0.153 \\
\hline rho & -0.198 & -0.198 & -0.198 & -0.198 \\
\hline $\begin{array}{l}\text { Censored } \\
\text { Observations }\end{array}$ & 430 & 430 & 430 & 430 \\
\hline
\end{tabular}




\section{References}

Ahlburg D., Amer M. 2003. "Labor Market Mobility among Egyptian Youth." Paper presented at the Research Workshop on Gender, Work and Family in the Middle East and North Africa, Mahdia Tunisia (June 8-'o, 2004).

Amer M., and Simonet V. 2008. "Labor Market Transition in Egypt: The Impact of First Employment Status." Paper presented at the $15^{\text {th }}$ ERF Conference. Cairo, Egypt, $23^{-25}$ November.

Anker R., Chernyshev I., Egger Ph., Mehran F., and Ritter, J . 2002. "Measuring Decent Work with Statistical Indicators." Policy Integration Department, Statistical Development and Analysis, Working Paper N. 2. International Labor Office, Geneva.

Assaad, R. (997.”The Effect of Public Sector Hiring and Policies on the Egyptian Labor Market". The World Bank Economic Revierw, Vol.II, No.I, pp-85-II8. http://www.jstor.org/stable/3990220. Accessed: 0I/07/2009 07:00

Assaad, Ragui and Fatma El-Hamidi. 2002. "Female Labor Supply in Egypt: Participation and Hours of Work." In Human Capital: Population Economics In The Middle East. Ismail Sirageldin (ed.). Cairo: American University in Cairo Press, pp. 210-230.

Assaad, R. and F. El-Hamidi 2009. "Women in the Egyptian Labor Market: An Analysis of Developments, 1988-2006." In The Egyptian Labor Market Revisited. Ragui Assaad (ed.) Cairo: The American University in Cairo Press, pp. 219-258.

Assaad, R., Binzel C., Gadallah M. 20IO. "Transition to Employment and Marriage among Young Men in Egypt". Submitted to Middle East Development Fournal August 2009. Revised February 2010.

Assaad, R., Roushdy R. and Rashed A. 2009. "Measuring and Operationalizing Job Quality in Egypt." Gender and Work in the MENA Region Working Papers Series. Number I, The Population Council, Cairo. Egypt.

Blazquez Cuesta M. 2006 . "Earnings Mobility and Low-Wage Employment in Spain: The Role of Job Mobility and Contractual Arrangements," LoWER Working Papers wpII, AIAS, Amsterdam Institute for Advanced Labour Studies. 
Buchel, F. and Merten,A. 200o. "Overeducation, Undereducation, and the Theory of Career Mobility". Forschungs institut zur Zukunft der Arbeit (IZA) Discussion Paper No. 195.

Davia M. 2005. "Job mobility and wage mobility at the beginning of the working career: a comparative view across Europe." ISER Working Papers, Number $2005^{-0} 3$.

Dex, S., Ward, K., Lindely, J. 2007. Vertical Occupational Mobility and its Measurement. GeNet Working Paper No 24.

El-Haddad, A. 2009, "Labor Market Gender Discrimination under Structural Adjustment: The Case of Egypt," Social Research Center Working Paper \#003, November: American University in Cairo.

El-Hamidi, F. 2003, "Poverty and Labor Supply of Women, Evidence from Egypt."

Paper Presented at the $\mathrm{IO}^{\text {th }}$ Annual conference of Economic Research Forum, Cairo, Egypt.

ERF 2006. Egyptian Labor Market Panel Survey, Egypt Labor Market surveys 1998 and 2006 Publicly Accessible Database, Economic Research Forum, Cairo, Egypt (www.erf.org.eg).

Greene, W. 2008. "Econometric Analysis". Sixth Edition. Pearson International edition.

Maltseva, I. 2005. "Gender Differences in occupational Mobility and Segregation at the Labor Market, The case of Russian” Economy Education and Research Consortium (EERC). Working paper series ISSN $156 I^{-2} 2422$

Pavlopous, D., Fouarge D., Muffels, R. and Vwemunt J. K 2007.'Job Mobility and Wage Mobility of High- and Low-Paid Workers. Fournal of Applied Social Science Studies, I27(I).

Perticara, M. 2004. "Wage Mobility Through Job Mobility," ILADES-Georgetown University Working Papers invi4I, IladesGeorgetown University, School of Economics and Business. http:// ideas.repec.org/p/ila/ilades/invi4I.html Accessed : I2/I2/2009

Royalty, A. I998. "Job-to-Job and Job-to-Non-employment Turnover by Gender and Education Level." Fournal of Labor Economics, I998, Vol. I6, No. 2

Waddoup, J.and Assane, D. Oct r993. Mobility and Gender in a Segment Labor Market: A Closer Look. Fournal of Economics and Sociology, Vol.52, No 4, pp-399-4I2. 
Welch, F. 2000. "Growth in Women's Relative Wage and in Inequality among Men: One Phenomenon or Two?. The American Economic Review, Vol. 90, No. 2, Papers and proceeding of One Hundred Twelfth Annual Meeting of the American Economic Association, March, pp:444-449.

Winter-Ebmer, R., and Zweimuller, J. I997. Unequal Assignment and unequal promotion in Job Ladder. Fournal of Labor Economics, Vol. I5, No. I, Part I, January, pp:43-71. 
Annex

Figure A-1

Working Life cycle of Females by Cohort

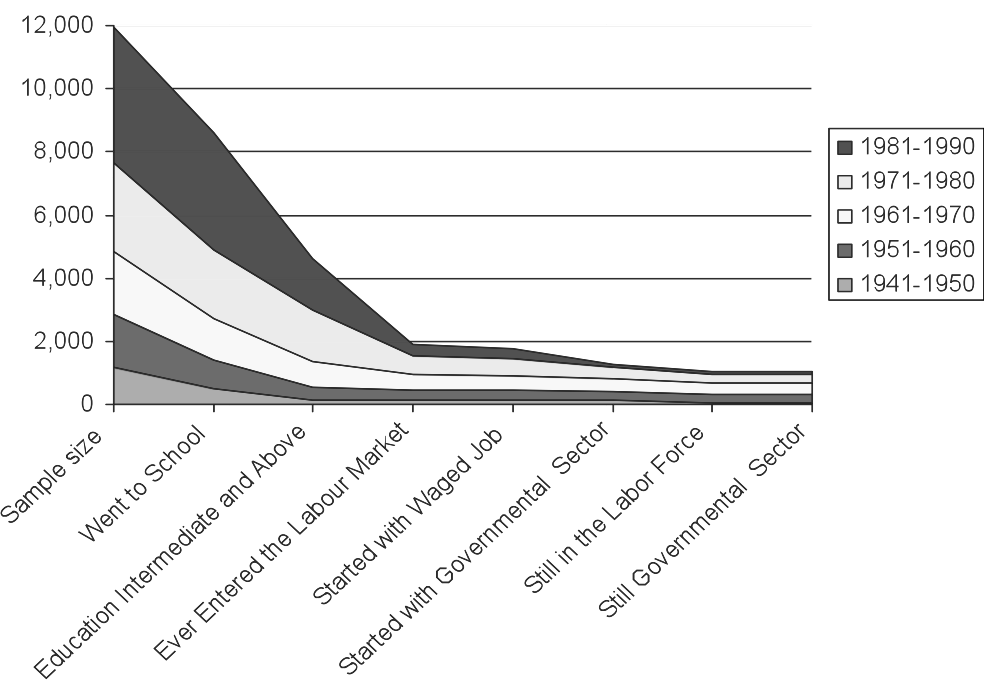

Table A-1: Working Life Cycle of Females by Cohort

\begin{tabular}{|c|c|c|c|c|c|c|c|c|}
\hline Cohort & $\begin{array}{c}\text { Sample } \\
\text { size }\end{array}$ & $\begin{array}{c}\text { Went to } \\
\text { School }\end{array}$ & $\begin{array}{c}\text { Education } \\
\text { Intermediate } \\
\text { and Above }\end{array}$ & $\begin{array}{c}\text { Ever } \\
\text { Entered } \\
\text { the } \\
\text { Labor } \\
\text { Market }\end{array}$ & $\begin{array}{c}\text { Started } \\
\text { with } \\
\text { Waged } \\
\text { Job }\end{array}$ & $\begin{array}{c}\text { Started in } \\
\text { Government } \\
\text { Sector }\end{array}$ & $\begin{array}{c}\text { Still } \\
\text { in the } \\
\text { Labor } \\
\text { Force }\end{array}$ & $\begin{array}{c}\text { Still in the } \\
\text { Government } \\
\text { Sector }\end{array}$ \\
\hline $\begin{array}{c}1941- \\
1950\end{array}$ & 1,168 & 491 & 157 & 127 & 127 & 122 & 59 & 55 \\
\hline $\begin{array}{c}1951- \\
1960\end{array}$ & 1,683 & 892 & 392 & 320 & 315 & 301 & 271 & 264 \\
\hline $\begin{array}{c}1961- \\
1970\end{array}$ & 2,015 & 1325 & 789 & 501 & 466 & 384 & 352 & 348 \\
\hline $\begin{array}{c}1971- \\
1980\end{array}$ & 2,799 & 2189 & 1,655 & 599 & 555 & 348 & 277 & 268 \\
\hline $\begin{array}{c}1981- \\
1990\end{array}$ & 4,305 & 3725 & 1625 & 347 & 284 & 109 & 96 & 94 \\
\hline
\end{tabular}


Table A-2: Percentage in Each Hourly Wage Quartile, Based on Whole Weighted Samples Aged 18-64 in 1998 and 2006, Intermediate Education and Above, Females

\begin{tabular}{|c|c|c|}
\hline Wage Quartiles* & \% of Females in $\mathbf{9 9 8}$ & \% of Females in $\mathbf{2 0 0 6}$ \\
\hline 1 & 34.2 & 24.2 \\
\hline 2 & 29.9 & 23.5 \\
\hline 3 & 26.4 & 28.5 \\
\hline 4 & 26.8 & 30.6 \\
\hline $\begin{array}{c}\text { \% in the Whole Waged } \\
\text { Sample }\end{array}$ & 29.4 & 26.6 \\
\hline
\end{tabular}

Source: Based on author's calculations from ELMS and ELMPS

Table A-3: Percentage in Each Job Security Index Quartile, Based on Whole Weighted Samples Aged 18-64 in 1998 and 2006, Intermediate Education and Above, Females

\begin{tabular}{|c|c|c|}
\hline $\begin{array}{c}\text { Job Security Index } \\
\text { Quartiles* }\end{array}$ & \% of Females in $\mathbf{1 9 9 8}$ & \% of Females in 2006 \\
\hline 1 & 24.1 & 14.1 \\
\hline 2 & 34.2 & 28.8 \\
\hline 3 & 37.1 & 31.1 \\
\hline 4 & 29.8 & 33 \\
\hline \% in the Waged Sample & 31.1 & 26.6 \\
\hline
\end{tabular}

* Quartiles' Values differ from Year to Year

Source: Based on author's calculations from ELMS and ELMPS

Table A-4: Descriptive Statistics of Selected Variables of the Target Panel Sample, Females

\begin{tabular}{|l|c|c|c|}
\hline & $\begin{array}{c}\text { Sample in 1998 } \\
\text { Aged 26-50 in } \\
\text { 2006* }\end{array}$ & Waged in 1998 & $\begin{array}{c}\text { Remained Waged } \\
\text { in 2006 }\end{array}$ \\
\hline $\begin{array}{l}\text { Individual } \\
\text { Characteristics }\end{array}$ & & & \\
\hline Age** $^{* *}$ & 28.5 & 32.1 & 33.2 \\
\hline Education** $^{*}$ & & & \\
\hline $\begin{array}{l}\text { Secondary \& } \\
\text { Intermediate }\end{array}$ & $63.8 \%$ & $46.9 \%$ & $44.9 \%$ \\
\hline Above Intermediate & $13.3 \%$ & $16.9 \%$ & $17.7 \%$ \\
\hline University \& Above & $22.9 \%$ & $36.3 \%$ & $37.5 \%$ \\
\hline & & & \\
\hline Married 1998** & $63 \%$ & $66.1 \%$ & $72.7 \%$ \\
\hline
\end{tabular}




\begin{tabular}{|c|c|c|c|}
\hline $\begin{array}{l}\text { Married between } 1998 \\
\& 2006^{* *}\end{array}$ & $22.4 \%$ & $15.5 \%$ & $9.8 \%$ \\
\hline Birth 1998 and $2006^{* *}$ & $54.3 \%$ & $37.7 \%$ & $34.9 \%$ \\
\hline \multicolumn{4}{|l|}{$\begin{array}{l}\text { Spouse or Father } \\
\text { Characteristics }\end{array}$} \\
\hline \multicolumn{4}{|l|}{ Education $^{* *}$} \\
\hline Illiterate & $11.2 \%$ & $8.9 \%$ & $6.8 \%$ \\
\hline Prim. or Prep. & $15.5 \%$ & $13.8 \%$ & $13.4 \%$ \\
\hline Intermediate & $37.3 \%$ & $32.2 \%$ & $33.9 \%$ \\
\hline Above Intermediate & $36.2 \%$ & $45.1 \%$ & $45.9 \%$ \\
\hline \multicolumn{4}{|l|}{ Occupation ${ }^{* *}$} \\
\hline $\begin{array}{l}\text { Professional } \\
\text { \& Managerial } \\
\text { \&Technicians }\end{array}$ & $57.1 \%$ & $67.1 \%$ & $68.2 \%$ \\
\hline Clerks \& Sales & $17.6 \%$ & $16.8 \%$ & $16.5 \%$ \\
\hline Agriculture \& Fishing & $4.5 \%$ & $2.1 \%$ & $1.8 \%$ \\
\hline Crafts \& Trade & $20.7 \%$ & $14.0 \%$ & $13.6 \%$ \\
\hline \multicolumn{4}{|l|}{ Mother Education } \\
\hline Illiterate & $64.8 \%$ & $58.6 \%$ & $58 \%$ \\
\hline Prim. or Prep. & $26.6 \%$ & $30.2 \%$ & $30.6 \%$ \\
\hline Intermediate & $5.2 \%$ & $6.2 \%$ & $6.6 \%$ \\
\hline Above Intermediate & $3.4 \%$ & $5.1 \%$ & $4.9 \%$ \\
\hline Wealth** & 0.42 & 0.60 & 0.62 \\
\hline Urban/Rural & $75.1 \%$ & $80.7 \%$ & $81.2 \%$ \\
\hline Project 1998 & $29.2 \%$ & $20.6 \%$ & $18.5 \%$ \\
\hline Job Characteristics & & Quit Waged Work & $\begin{array}{c}\text { Continued Waged } \\
\text { Work }\end{array}$ \\
\hline Experience 1st job & & 5.5 & 10.4 \\
\hline Experience current job & & 2.8 & 8.9 \\
\hline $\begin{array}{l}\text { Sector in } 1998 \text { (\% of } \\
\text { Public) }\end{array}$ & & $45.7 \%$ & $90.5 \%$ \\
\hline $\begin{array}{l}\text { Wage in } 1998 \text { (Hourly } \\
\text { Mean Wage) }\end{array}$ & & 1.7 & 2.1 \\
\hline Job Security in 1998 & & -0.36 & 0.66 \\
\hline
\end{tabular}




\begin{tabular}{|c|c|}
\hline $\begin{array}{l}\text { Occupation in } 2006 \text { (\% } \\
\text { of Professionals) }\end{array}$ & $74 \%$ \\
\hline $\begin{array}{l}\text { Professional (Mean } \\
\text { Wage Difference) }{ }^{2}\end{array}$ & 0.73 \\
\hline $\begin{array}{l}\text { Non Professional (Mean } \\
\text { Wage Difference) }\end{array}$ & 0.68 \\
\hline $\begin{array}{l}\text { Changed Job from } 1998 \\
\text { to } 2006\end{array}$ & $19.8 \%$ \\
\hline $\begin{array}{l}\text { Yes (Mean Wage } \\
\text { Difference) }\end{array}$ & 0.74 \\
\hline $\begin{array}{l}\text { No (Mean Wage } \\
\text { Difference) }\end{array}$ & 0.68 \\
\hline Maternity leave* & $12.7 \%$ \\
\hline $\begin{array}{l}\text { Yes (Mean Wage } \\
\text { Difference) }\end{array}$ & 0.51 \\
\hline $\begin{array}{l}\text { No (Mean Wage } \\
\text { Difference) }\end{array}$ & 0.72 \\
\hline
\end{tabular}

1 - * Significant at the univariate level

2- ** Significant at the univariate level for wage work in 1998 continuing to work in 2006

3- Those who were studying in 1998 were excluded from the sample

4- Professionals, Mangers, Technicians vs. Clerks and Sales 
Table A-5: Descriptive Statistics of Selected Variables of the Target Panel Sample, Males

\begin{tabular}{|c|c|c|c|}
\hline & $\begin{array}{c}\text { Sample in } 98 \\
\text { aged } 26-50 \text { in } \\
2006^{*}\end{array}$ & Waged in 1998 & $\begin{array}{l}\text { Remained waged } \\
\text { in } 2006\end{array}$ \\
\hline \multicolumn{4}{|l|}{ Individual Characteristics } \\
\hline Age in $1998^{* *}$ & 28.8 & 31.1 & 31.0 \\
\hline \multicolumn{4}{|l|}{ Education in $1998^{* *}$} \\
\hline Secondary \& Intermediate & $61.5 \%$ & $56.3 \%$ & $54.7 \%$ \\
\hline Above Intermediate & $12.9 \%$ & $14.3 \%$ & $14.6 \%$ \\
\hline University \& Above & $25.6 \%$ & $29.4 \%$ & $30.7 \%$ \\
\hline Married $1998^{* *}$ & $41 \%$ & $54 \%$ & $55.6 \%$ \\
\hline $\begin{array}{l}\text { Married between } 1998 \text { \& } \\
2006^{* *}\end{array}$ & $34.5 \%$ & $30.0 \%$ & $30.4 \%$ \\
\hline \multicolumn{4}{|l|}{ Birth 1998 and 2006} \\
\hline \multicolumn{4}{|l|}{$\begin{array}{l}\text { Spouse or Father } \\
\text { Characteristics }\end{array}$} \\
\hline \multicolumn{4}{|l|}{ Education** } \\
\hline Illiterate & $39.0 \%$ & $37 \%$ & $36.8 \%$ \\
\hline Prim. or Prep. & $40.7 \%$ & $43.1 \%$ & $43.1 \%$ \\
\hline Intermediate & $11.5 \%$ & $11.1 \%$ & $11.0 \%$ \\
\hline Above Intermediate & $8.8 \%$ & $8.8 \%$ & $9.2 \%$ \\
\hline \multicolumn{4}{|l|}{ Occupation } \\
\hline $\begin{array}{l}\text { Professional \& Managerial } \\
\text { \&Technicians }\end{array}$ & $34.9 \%$ & $34.0 \%$ & $34.7 \%$ \\
\hline Clerks \& Sales & $18.2 \%$ & $19.3 \%$ & $18.2 \%$ \\
\hline Agriculture \& Fishing & $21.8 \%$ & $21.1 \%$ & $21.9 \%$ \\
\hline Crafts \& Trade & $25.1 \%$ & $25.7 \%$ & $25.2 \%$ \\
\hline \multicolumn{4}{|l|}{ Mother Education } \\
\hline Illiterate & 71.5 & 69.8 & 70.0 \\
\hline
\end{tabular}




\begin{tabular}{|l|c|c|c|}
\hline Prim. or Prep. & 21.2 & 23.3 & 23.3 \\
\hline Intermediate & 4.4 & 3.9 & 3.5 \\
\hline Above Intermediate & 2.9 & 3.0 & 3.1 \\
\hline & & & \\
\hline Wealth** & 0.19 & 0.24 & 0.24 \\
\hline Urban/Rural & $69.5 \%$ & $72.1 \%$ & $71.3 \%$ \\
\hline Project 98 & $35.9 \%$ & $23.1 \%$ & $22.7 \%$ \\
\hline & & & Continued as \\
\hline Job Characteristics & & Dropped Waged & Work \\
\hline Experience 1st job** 1998 & 9.6 & 9.9 & 10.1 \\
\hline Experience current job 2006 & 10.3 & 11.6 & 12.1 \\
\hline $\begin{array}{l}\text { Sector in 1998 (\% of } \\
\text { Public)** }\end{array}$ & & $61.1 \%$ & $65.5 \%$ \\
\hline $\begin{array}{l}\text { Wage in 1998 (Hourly mean } \\
\text { wage)* }\end{array}$ & & 2.1 & 2.1 \\
\hline Job security in 1998* & & 0.33 & 0.38 \\
\hline Occupation in 2006* & & & $0.5 \%$ \\
\hline $\begin{array}{l}\text { Professionals \& Managers\& } \\
\text { Technicians (Mean Wage } \\
\text { Difference) }\end{array}$ & & & 0.58 \\
\hline $\begin{array}{l}\text { Clerks \& Sales (Mean Wage } \\
\text { Difference) }\end{array}$ & & & 0.54 \\
\hline $\begin{array}{l}\text { Agriculture - fishing - crafts } \\
\text { \&trading (Mean Wage } \\
\text { Difference) }\end{array}$ & & & \\
\hline $\begin{array}{l}\text { Changed Job from 1998 to } \\
\text { 2006 }\end{array}$ & & & $0.6 \%$ \\
\hline Yes (Mean Wage Difference) & & & \\
\hline No (Mean Wage Difference) & & & \\
\hline
\end{tabular}

1 - * Significant at the univariate level

1 - * Significant at the univariate level for wage work in 1998 continuing to work in 2006

2-Those who were studying in 1998 were excluded from the sample 
Figure A-2: Log Real Hourly Wage Distribution in 1998 and 2006 (2006=100) for the Female Panel Sample, by Age Group, Intermediate Education and Above

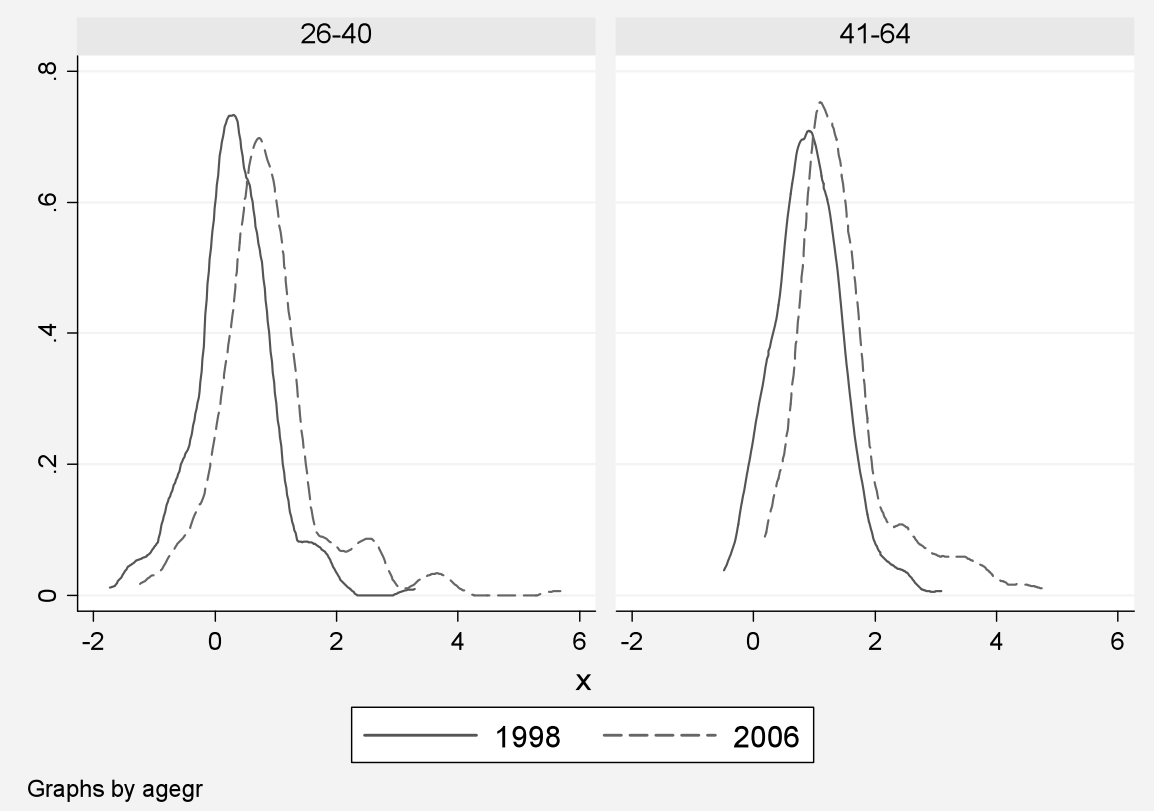

Figure A-3: Log Real Hourly Wage Distribution in 1998 and 2006 (2006=100) for the Male Panel Sample, by Age Group, Intermediate Education and Above

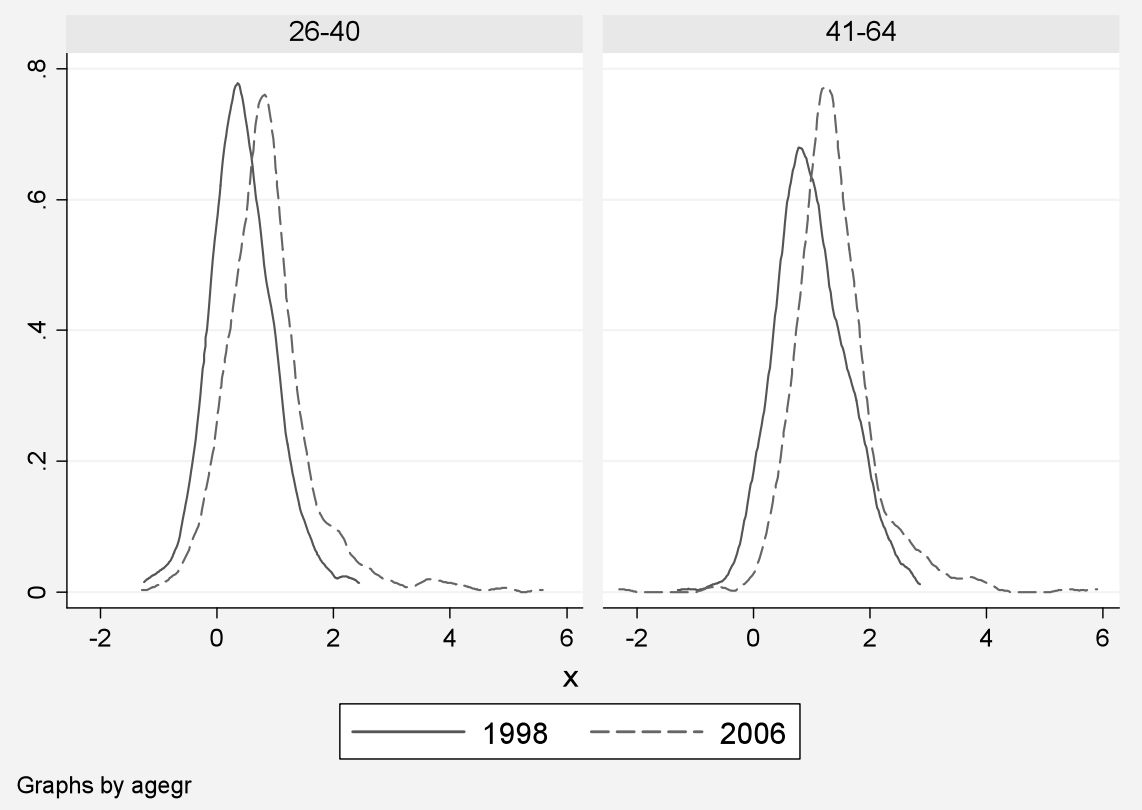



